\title{
16. PLIOCENE-PLEISTOCENE RADIOLARIANS FROM THE EAST PACIFIC RISE AND THE GALAPAGOS SPREADING CENTER, DEEP SEA DRILLING PROJECT LEG 54
}

\author{
Robert M. Goll, Duke University Marine Laboratory, Beaufort, North Carolina
}

\begin{abstract}
On Leg 54, a total of 760.9 meters of sediment was penetrated, of which 391.5 meters was recovered. In all, 331 samples were prepared and examined for radiolarians, which comprise a diverse fauna exhibiting variable degrees of preservation. A small fraction (28 taxa) of this assemblage from the East Pacific Rise and Galapagos Spreading Center are discussed and tabulated from this sample set. A modified radiolarian biozonation is proposed for correlating the recovery from the 16 holes drilled on Leg 54.

Seven new biozones are defined. Five new taxa include: $\mathrm{Am}$ phispyris roggentheni, Neosemantis hofferti, Nephrospyris renilla lana, Pseudocubus warreni, and Sphaerozoum crassus.
\end{abstract}

\section{INTRODUCTION}

The 16 holes drilled on Leg 54 are located at 11 sites that are clustered in two regions of the eastern equatorial Pacific: the west flank of the East Pacific Rise (EPR), Sites 419-423 and 426-429; and the Galapagos Spreading Center (GSC), Sites 424 and 425 (Figure 1). Sediments older than about $2.2 \mathrm{~m} . \mathrm{y}$. were not recovered on this leg, and radiolarians occur in the recovery of all the holes, although the quality of preservation is quite variable. Much of the drilling activity took place on the EPR in an effort to sample young crustal rocks in a region of rapid spreading with only a thin veneer of sediment. The thickness of the sediment column ranged from zero (Site 426) to 118.5 meters (Site 420). Sediment coring was a low-priority objective on this leg, and the sediment columns were cored continuously at only four of the nine EPR sites.

These EPR sites are located at approximately $8^{\circ}-9^{\circ} \mathrm{N}$, and some biostratigraphic indicator radiolarians with restricted equatorial provinces are not represented in these assemblages or are too scarce to be useful. Other species that are not typical components of equatorial assemblages also occur in the EPR recovery, and this subfauna is assumed to have been derived from the California Current. Consequently, this assemblage is characterized by remarkably high diversity, and few species occur so frequently that their occurrence could be characterized as abundant or even common. The combination of these two factors leads to biostratigraphic problems, because the biozonation of Riedel and Sanfilippo (1978) is not sufficiently detailed in the Pleistocene to capably treat this young sediment, and only two of the biozones of $\mathrm{Ni}$ grini (1971) could be recognized consistently. I propose here a new Pleistocene biozonation for the radiolarians, that is in part a modification of previous systems and additionally includes seven new biozones (Table 1).

The recovery from the GSC contains a normal equatorial radiolarian fauna with strong input from the
Peru Current. However, the same radiolarian biozonation was employed at these sites for the sake of uniformity and the higher degree of resolution it provides.

Usage of zonal nomenclature and terms such as "advent level" follows the International Subcommission on Stratigraphic Classification (1976).

\section{PRESERVATION}

Sediments at the EPR sites younger than approximately $0.65 \mathrm{~m}$.y. consist of calcareous oozes with 10-30 per cent clay minerals presumably of Central American origin. Radiolarians are scarce to common in these oozes, but preservation is only poor to moderate. The partial dissolution of radiolarians as well as other siliceous microfossils in this sedimentary association is attributable to the corrosive effect of terrigenous clay minerals, which Johnson (1976) reported for this region. In the upper 10 meters of the sediment columns at Sites 419-423 and 428, these calcareous oozes are interbedded with brown clays typical of the north central $\mathrm{Pa}$ cific. Radiolarians are much better preserved in the samples from these interbedded intervals, but the quality of preservation decreases downcore. Brown clay does not occur at the surface at Sites 427 and 429, and radiolarians are poorly preserved in these sediments.

Radiolarian preservation improves markedly in older sediments at the EPR sites, where diatomites and volcanic ash layers are interbedded in the calcareous oozes. These additional opaline particles presumably provide sufficient dissolved silica to pore waters to retard radiolarian dissolution in the entire lower part of the sediment column, in spite of the continued presence of clay minerals in approximately the same concentrations as the younger sediments. Site 427 is located in the Siqueiros fracture zone, where sedimentation appears to have been influenced more highly by bottom currents than the other EPR sites, and diatomites occur higher in the sediment column, with concomitant excellent radiolarian preservation in sediments as young as 0.4 m.y. 


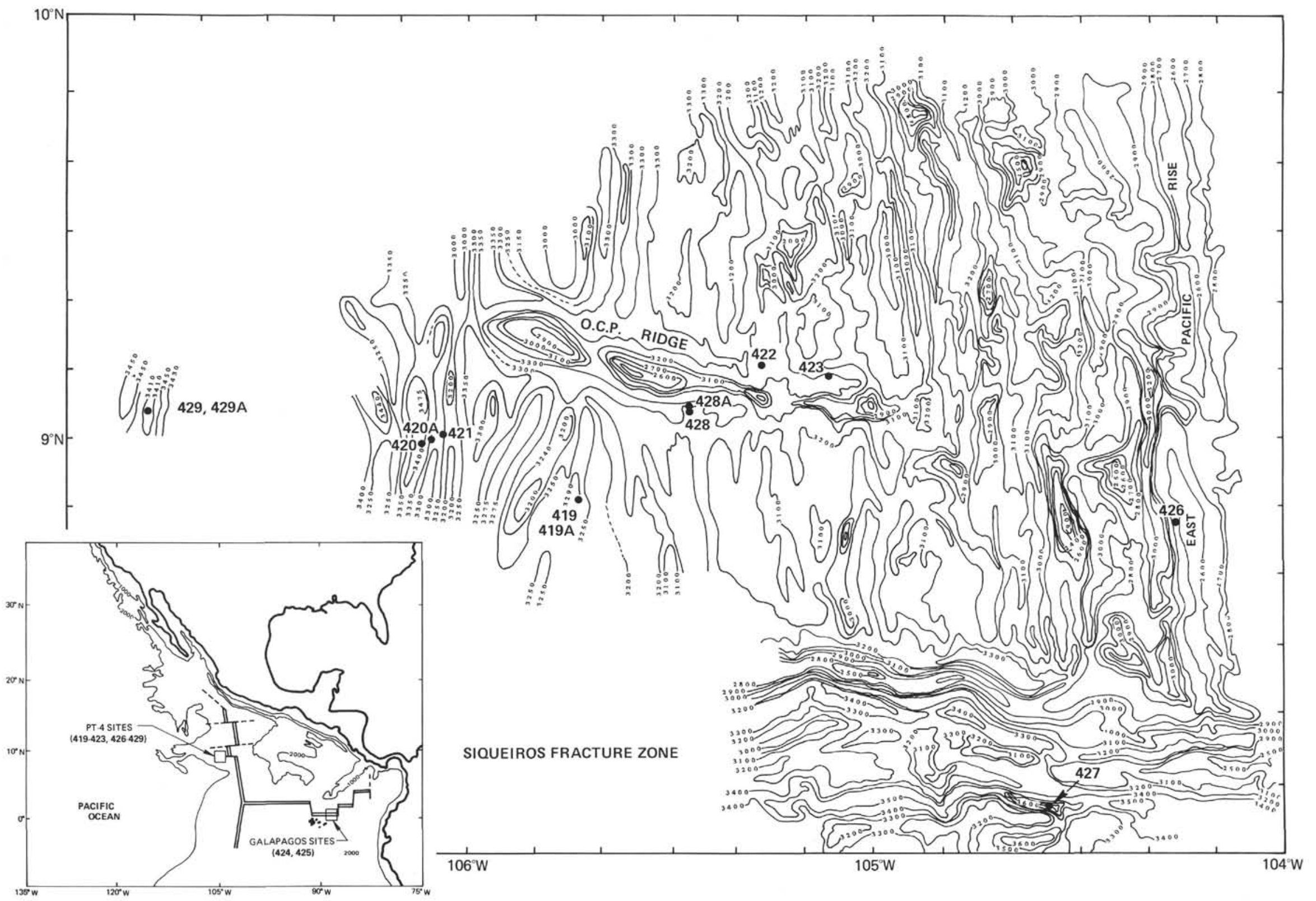

Figure 1. Location of sites drilled in the East Pacific Rise and Galapagos Spreading Center during Leg 54. 
TABLE 1

Comparison of the Radiolarian Biozonation for Leg 54 Sediments and Other Radiolarian Biozonations

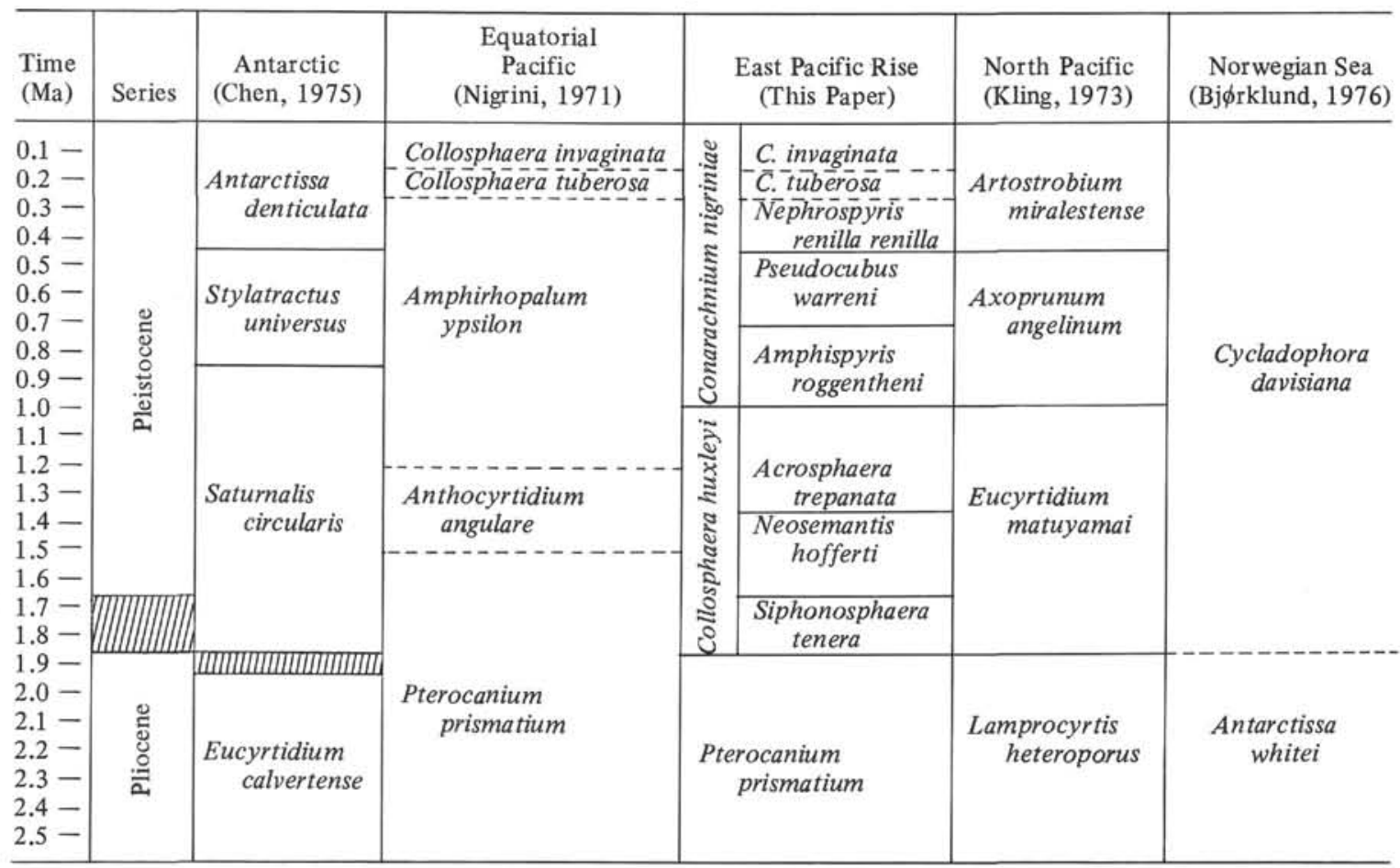

Except in the diatomites, clay minerals in the EPR recovery are somewhat refractory and cannot be separated easily from the radiolarian residue.

Radiolarians are abundant and very well preserved in the sediments at Site 425 (GSC) and, to a much lesser degree, at Site 424 . Clay minerals of presumably the same primary source occur in concentrations of 10-30 per cent at these sites; however, radiolarian preservation is improved here because of the higher biological productivity of the surface water, which results in a greater flux of opal debris to the sea floor. These clay minerals are not as refractory as those of the EPR recovery and can be separated easily from the radiolarian residue. Radiolarian preservation must have been detrimentally affected by hydrothermal activity at Site 424 . Radiolarians are absent or poorly preserved in both the hydrothermal muds and, generally, in the underlying calcareous ooze. Radiolarians are well preserved only in the surface ooze overlying the hydrothermal mud at Holes $424,424 \mathrm{~A}$, and $424 \mathrm{~B}$, as well as throughout the mudline core at Hole $424 \mathrm{C}$, which is located on the margin of the mounds field.

Radiolarians are poorly preserved in the lowest 5 to 10 meters of the sediment column directly above basalt at some of the Leg 54 sites. Similar associations have been observed in basal sediments of other DSDP sites, and dissolution of opaline particles may be enhanced on young crust. Exceptions to this generalization are Holes 419,424 , and 424B, where basal sediments contain abundant volcanic glass. Radiolarians are also abundant in basal sediments of Holes 421 and 425 , which contain significant concentrations of iron oxides. The reason for moderate radiolarian preservation in the basal sediments at Hole 423 is not immediately apparent, although these sediments contain traces of volcanic glass.

\section{RADIOLARIAN BIOZONATION}

Hole 420 was chosen as the reference section for Leg 54 , because it includes the oldest sediments and thickest sediment column (118.5 m), was most completely cored, and appears to have undergone continuous and reasonably uniform sedimentation. It soon became apparent for reasons discussed in the introduction that major changes in the radiolarian biozonation would be necessary to effectively treat this recovery. Pterocanium prismatium has only trace and sporadic occurrences at Hole 420 , and its extinction level occurs approximately 20 meters above the Pliocene/Pleistocene boundary as determined by other microfossils. Riedel and Sanfilippo (1978) emended the definition of the $P$. prismatium Zone such that its top coincides with the first appearance of Conarachnium nigriniae (Lamprocyrtis haysi of these authors). However, $C$. nigriniae did not evolve until $0.9 \mathrm{Ma}$., and there is an approximately 20 -meter gap at Hole 420 between the last occurrence of $P$. prismati$u m$ and the first appearance of $C$. nigriniae. Moreover, such an emendation results in the absence of a Pliocene/ Pleistocene zonal boundary for the radiolarians and a loss of resolution within the expanded $P$. prismatium Interval-zone ( 0.9 to 2.5 m.y. time span). Consequently, it is desirable to define a new zone between the $P$. prismatium and $C$. nigriniae zones. The $C$. nigrinae Rangezone of Riedel and Sanfilippo (1978) is adopted unchanged, but the $P$. prismatium Zone must be further emended such that its top coincides with the first appearance of Collosphaera huxleyi. Fortunately, C. hux- 
leyi is a common-to-abundant species in the lower Pleistocene recovery of Leg 54, whose first appearance is coincident with the base of the Crenalithus doronicoides Zone (calcareous nannofossils) and Nitzschia reinholdii Zone (diatoms), and thus provides a radiolarian marker for the base of the Pleistocene. This system divides the Pleistocene into two units of approximately equal duration $(0.9$ m.y.). The $C$. huxleyi Interval-zone and the $C$. nigriniae Range-zone are subdivided into a series of eight subzones that will be defined in the following discussion. The geographic applicability of these zones is not known at the present time.

\section{Pliocene}

Pterocanium prismatium Interval-zone (emended definition)

Base - extinction level of Stichocorys peregrina.

Top - advent level of Collosphaera huxleyi.

Type locality and type section - unspecified.

Remarks - This zone can be identified only at Holes 419 and 420 . The $C$. huxleyi Interval-zone contains the Androspyris fenestra$t a \rightarrow$ Androspyris anthropiscus transition as well as the local disappearance level of $A$. fenestrata and the advent levels of Acrosphaera trepanata and Sphaerozoum crassus n. sp.

\section{Lower Pleistocene}

Collosphaera huxleyi Interval-zone (new zone)

Base - advent level of Collosphaera huxleyi $(1.8 \mathrm{Ma})$. Top - advent level of Conarachnium nigriniae (0.9-1.09 Ma). Type locality - Hole 420 .

Type section - top of Core 7 ( $52.0 \mathrm{~m}$ below the sea floor) to base of Core 10 ( $90.0 \mathrm{~m}$ below the sea floor).

Remarks - The base of the C. huxleyi Interval-zone at Hole $\mathbf{4 2 0}$ coincides approximately with the base of the Nitzschia reinholdii Zone, but its relationship to the calcareous nannofossil biozonation here is ambiguous because of the erratic distribution of these microfossils in Cores 9 and 10. The bases of the $C$. huxleyi and Crenalithus doronicoides zones coincide at Hole 419, however. The name of this zone may require revision because of uncertainty concerning the identity of the nominate species. The $C$. huxleyi Interval-zone is subdivided into three subzones as follows:

Siphonosphaera tenera Interval-zone (new zone)

Base - advent level of Collosphaera huxleyi (1.8 Ma).

Top - advent level of Neosemantis hofferti n. sp. (1.58 Ma).

Type locality - Hole 420 .

Type section - Core 10 ( 80.5 to $90.0 \mathrm{~m}$ below the sea floor).

Remarks - The $S$. tenera Interval-zone has been recognized in Holes $419,420,428$, and possibly 429 . This short zone contains the advent level of Tholospyris devexa devexa as well as the temporary disappearance of Acrosphaera trepanata. The nominate taxon is a long-ranging, extant species that is scarce but persistent in Leg 54 recovery. The base of its stratigraphic range is unknown.

Neosemantis hofferti Concurrent range-zone (new zone)

Base - advent level of Neosemantis hofferti n. sp. (1.58 Ma). Top - extinction level of Sphaerozoum crassus n. sp. (1.28 Ma). Type locality - Hole 420.

Type section - top of Core 8 ( $61.5 \mathrm{~m}$ below the sea floor) to the base of Core 9 ( $80.5 \mathrm{~m}$ below the sea floor).

Remarks - The $N$. hofferti Concurrent range-zone includes the extinction level of $P$. prismatium, and its top is marked by the abrupt extinction level of Sphaerozoum crassus at Hole 420. The Lamprocyrtis heteroporus $\rightarrow$ Lamprocyrtis neoheteroporus transition occurs within this zone, as does the extinction level of $L$. heteroporus. The nominate species is quite scarce, and great care must be exercised to recognize this zone, which was observed at Holes 420,421, and 425 (Table 2). The ages of the top and base of this zone are known only from interpolation of the sediment accumulation curve for Hole 420 .

Acrosphaera trepanata Interval-zone (new zone)

Base - extinction level of Sphaerozoum crassus n. sp. (1.28 Ma). Top - advent level of Conarachnium nigriniae (0.91 to $1.09 \mathrm{Ma}$ ). Type locality - Hole 420

Type section - Core 7 inclusive (52.0 to $61.5 \mathrm{~m}$ below the sea floor).
Remarks - This zone includes the extinction level of Acrosphaera cyrtodon and the probable advent level of Nephrospyris renilla renilla as well as the local appearance level of Anthrocyrtidium angulare. The zone must be identified with caution, because its base is not marked by the first appearance of $A$. trepanata but by the reappearance of this species after an absence of about $0.4 \mathrm{~m}$.y. in the eastern equatorial Pacific. The associated fauna, such as Lamprocyrtis neoheteroporus and Tholospyris devexa devexa, must be identified in order to confirm the existence of this zone. The absence of Sphaerozoum crassus n. sp. also represents important negative evidence of this zone, which was recognized at Sites 420 , 425 , and 428 (Table 2).

\section{Upper Pleistocene}

Conarachnium nigriniae Range-zone (Riedel and Sanfilippo, 1978)

Base - advent level of Conarachnium nigriniae $(0.91 \mathrm{Ma})$.

Top - modern sea floor.

Type locality and section - unspecified.

Remarks - This is the same zone that Riedel and Sanfilippo (1978) designated the Lamprocyrtis haysi Zone. These authors indicate that the advent level of the nominate species is coincident with the Pliocene/Pleistocene boundary, but I have interpolated the age of this event in equatorial Pacific sediments as $0.91 \mathrm{Ma}$ on the basis of my examination of Lamont-Doherty piston cores with magnetic stratigraphy (V24-59 and RC12-66). Kling (1973) indicated its advent level as somewhat later in North Pacific sediments (0.4-0.9 Ma). If the sediment accumulation curve for Hole 420 is correct, then $C$. nigriniae must have its evolutionary first appearance at $1.09 \mathrm{Ma}$, but $0.91 \mathrm{Ma}$ has been adopted here as the age of this event. The $C$. nigriniae Range-zone was recognized at all the Leg 54 sites except Site 429; it is subdivided into five subzones as follows.

Amphispyris roggentheni Concurrent range-zone (new zone)

Base - advent level of Conarachnium nigriniae ( $0.91 \mathrm{Ma})$

Top - extinction level of Amphispyris roggentheni n. sp. (0.65 Ma). Type locality - Hole 420 .

Type section - top of Core $5(33.0 \mathrm{~m}$ below the sea floor) to base of Core $6(52.0 \mathrm{~m}$ below the sea floor $)$.

Remarks - The nominate species is quite scarce but easily recognized because of its large size. Its occurrence can be most easily traced by scanning slides with a low power objective (X4). The A. roggentheni Concurrent range-zone includes the extinction levels of Anthocrytidium angulare and Lamprocyrtis neoheteroporus, and it was recognized at Sites $419,420,422,423,425,427$, and 428 (Table 2).

Pseudocubus warreni Interval-zone (new zone)

Base - extinction level of Amphispyris roggentheni n. sp. (0.65 Ma). Top - extinction level of Stylatractus universus $(0.40 \mathrm{Ma}$

Type locality - Hole 427 .

Type section - top of Core 3 (13.0 m below the sea floor) to Core 6 , Section 2 ( $62.0 \mathrm{~m}$ below the sea floor).

Remarks - The extinction level of Stylatractus universus has been used as the top of the Stylatractus universus Zone of Chen (1975) and the Axoprunum angelinum Zone of Kling (1973). A different nominate species has been designated for the present interval zone in order to avoid confusion with these other zones, which are differently defined at their bases. Johnson and Knoll (1975) determined the age of the extinction level of $S$. universus to be 0.31-0.34 Ma. Hays and Shackleton (1976) and Morley and Shackleton (1978) have used the $\delta^{18} \mathrm{O}$ record to establish this datum at 0.41-0.425 Ma. The $P$. warreni Interval-zone includes the Androspyris anthropiscus $\rightarrow$ Androspyris huxleyi transition and the extinction level of Neosemantis hofferti $\mathrm{n}$. sp., although these three species have sporadic occurrences in Leg 54 recovery. The zone was observed in Holes 420, 422, 423, 424, 424A, 424B, 425, and 427 (Table 2).

Nephrospyris renilla renilla Interval-zone (new zone) Base - extinction level of Stylatractus universus $(0.40 \mathrm{Ma})$. Top - advent level of Collosphaera tuberosa (?0.20 Ma). Type locality - provisionally Hole 427 .

Type section - Core 2 inclusive ( 3.5 to $13.0 \mathrm{~m}$ below the sea floor). Remarks - This zone occurs in the part of the recovery where radiolarian preservation is particularly poor, and there is no good type section in the Leg 54 recovery. Moreover, the zone must be recognized on the basis of the absence of index species. Johnson and Knoll (1975) found the stratigraphic ranges of the two boun- 
TABLE 2

Occurrences of the Radiolarian Biozones in the Recovery from Each Hole, DSDP Leg 54

\begin{tabular}{|c|c|c|c|c|c|c|c|c|c|c|c|c|c|c|c|c|}
\hline Biozonation & 419 & $419 \mathrm{~A}$ & 420 & $420 \mathrm{~A}$ & 421 & 422 & 423 & 424 & $424 \mathrm{~A}$ & $424 \mathrm{~B}$ & $424 \mathrm{C}$ & 425 & 427 & 428 & 429 & $429 \mathrm{~A}$ \\
\hline $\begin{array}{c}\text { Collosphaera } \\
\text { invaginata }\end{array}$ & - & - & $\begin{array}{c}1-1 \\
(19-21 \mathrm{~cm})\end{array}$ & - & - & $\begin{array}{c}1-1 \\
(19-21 \mathrm{~cm})\end{array}$ & $\begin{array}{c}1-1 \\
(30-32 \mathrm{~cm}) \\
\vdots \\
2-1 \\
(20-22 \mathrm{~cm})\end{array}$ & $\begin{array}{c}1-1 \\
(0-2 \mathrm{~cm})\end{array}$ & - & - & $\begin{array}{c}1-1 \\
(19-21 \mathrm{~cm})\end{array}$ & - & - & $\begin{array}{c}1-1 \\
(39-41 \mathrm{~cm}) \\
1 \\
1-2 \\
(19-21 \mathrm{~cm}) \\
\end{array}$ & \multirow{5}{*}{ 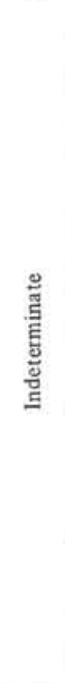 } & - \\
\hline $\begin{array}{c}\text { Collosphaera } \\
\text { tuberosa }\end{array}$ & $\begin{array}{c}2-1 \\
(29-31 \mathrm{~cm})\end{array}$ & $\begin{array}{c}1-1 \\
(47-49 \mathrm{~cm}) \\
4 \\
1-2 \\
(19-21 \mathrm{~cm}) \\
\end{array}$ & $\begin{array}{c}2-1 \\
(10-12 \mathrm{~cm}) \\
\vdots \\
3-1 \\
(28-30 \mathrm{~cm}) \\
\end{array}$ & $\begin{array}{c}1-1 \\
1 \\
1-2\end{array}$ & $\begin{array}{c}1-3 \\
4 \\
1-6\end{array}$ & $\begin{array}{c}1-1 \\
(120-122 \mathrm{~cm})\end{array}$ & $\begin{array}{c}2-2 \\
(20-22 \mathrm{~cm}) \\
4 \\
2-3 \\
(20-22 \mathrm{~cm})\end{array}$ & & - & $\begin{array}{c}1-1 \\
(20-22 \mathrm{~cm}) \\
1 \\
1-2 \\
(20-22 \mathrm{~cm}) \\
\end{array}$ & $\begin{array}{c}1-2 \\
(19-21 \mathrm{~cm}) \\
\downarrow \\
1-5 \\
(19-21 \mathrm{~cm})\end{array}$ & $\begin{array}{c}1-1 \\
(20-22 \mathrm{~cm}) \\
\vdots \\
2-3 \\
(19-21 \mathrm{~cm}) \\
\end{array}$ & $\begin{array}{c}1-2 \\
(20-22 \mathrm{~cm})\end{array}$ & - & & \\
\hline $\begin{array}{l}\text { Nephrospyris } \\
\quad \text { renilla renilla }\end{array}$ & - & & - & & - & - & & $\begin{array}{c}3-3 \\
(30-32 \mathrm{~cm})\end{array}$ & $\begin{array}{c}1-1 \\
(19-21 \mathrm{~cm})\end{array}$ & - & & $\begin{array}{c}2-4 \\
(19-21 \mathrm{~cm}) \\
\downarrow \\
2, \mathrm{CC}\end{array}$ & $\begin{array}{c}2-1 \\
(40-42 \mathrm{~cm}) \\
\vdots \\
2-6 \\
(96-98 \mathrm{~cm})\end{array}$ & - & & \\
\hline $\begin{array}{l}\text { Pseudocubus } \\
\text { warreni }\end{array}$ & - & & $\begin{array}{c}3-5 \\
(19-21 \mathrm{~cm}) \\
\downarrow \\
4, \mathrm{CC}\end{array}$ & & - & $\begin{array}{c}3-4 \\
(9-11 \mathrm{~cm}) \\
? ! ? \\
3-6 \\
(19-21 \mathrm{~cm})\end{array}$ & $\begin{array}{c}3-4 \\
(20-22 \mathrm{~cm})\end{array}$ & $\begin{array}{c}4-2 \\
(39-41 \mathrm{~cm}) \\
4 \\
4-6 \\
(19-21 \mathrm{~cm})\end{array}$ & $\begin{array}{c}2-1 \\
(19-21 \mathrm{~cm})\end{array}$ & $\begin{array}{c}4-3 \\
(20-22 \mathrm{~cm})\end{array}$ & & $\begin{array}{c}3-1 \\
(19-21 \mathrm{~cm}) \\
\vdots \\
3-6 \\
(19-21 \mathrm{~cm})\end{array}$ & $\begin{array}{c}3-1 \\
(90-92 \mathrm{~cm}) \\
\vdots \\
6-2 \\
(19-21 \mathrm{~cm}) \\
\end{array}$ & & & \\
\hline $\begin{array}{l}\text { Amphispyris } \\
\text { roggentheni }\end{array}$ & $\begin{array}{c}4-1 \\
(14-16 \mathrm{~cm}) \\
4 \\
4, \mathrm{CC}\end{array}$ & & $\begin{array}{c}5 \cdot 1 \\
(19-21 \mathrm{~cm}) \\
+ \\
6, \mathrm{CC}\end{array}$ & & - & $\begin{array}{c}3, \mathrm{CC} \\
\vdots \\
8-3 \\
(61-63 \mathrm{~cm})\end{array}$ & $\begin{array}{c}4-4 \\
(17-19 \mathrm{~cm}) \\
5-4 \\
(25-27 \mathrm{~cm})\end{array}$ & & & & & $\begin{array}{c}3-7 \\
(19-21 \mathrm{~cm}) \\
4 \\
4, \mathrm{CC}\end{array}$ & $\begin{array}{c}6-5 \\
(19-21 \mathrm{~cm}) \\
\downarrow \\
8-6 \\
(148-150 \mathrm{~cm})\end{array}$ & $\begin{array}{c}2-1 \\
(23-25 \mathrm{~cm}) \\
\vdots \\
3-3 \\
(19-21 \mathrm{~cm}) \\
\end{array}$ & & \\
\hline $\begin{array}{c}\text { Acrosphaera } \\
\text { trepanata }\end{array}$ & - & & $\begin{array}{c}7-1 \\
(19-21 \mathrm{~cm}) \\
\downarrow \\
7, \mathrm{CC}\end{array}$ & & - & & & & & & & $\begin{array}{c}5-1 \\
(19-21 \mathrm{~cm}) \\
+ \\
5, \mathrm{CC}\end{array}$ & & $\begin{array}{c}3-4 \\
(19-21 \mathrm{~cm}) \\
\vdots \\
4-2 \\
(19-21 \mathrm{~cm})\end{array}$ & & \\
\hline $\begin{array}{l}\text { Neosemantis } \\
\text { hofferti }\end{array}$ & - & & $\begin{array}{c}8-1 \\
(19-21 \mathrm{~cm}) \\
\vdots \\
9, \mathrm{CC} \\
\end{array}$ & & $\begin{array}{c}2-1 \\
(7-9 \mathrm{~cm})\end{array}$ & & & & & & & $6, \mathrm{CC}$ & & - & & $\begin{array}{c}\uparrow \\
\text { or } \\
\text { higher }\end{array}$ \\
\hline $\begin{array}{l}\text { Siphonosphaera } \\
\text { tenera }\end{array}$ & $\begin{array}{c}5-1 \\
(92-94 \mathrm{~cm}) \\
\vdots \\
5-2 \\
(31-33 \mathrm{~cm})\end{array}$ & & $\begin{array}{c}10-1 \\
(20-22 \mathrm{~cm}) \\
\downarrow \\
10, \mathrm{CC}\end{array}$ & & & & & & & & & & & $\begin{array}{c}4-3 \\
(19-21 \mathrm{~cm}) \\
\vdots \\
5-2 \\
(19-21 \mathrm{~cm})\end{array}$ & & $\begin{array}{c}1-1 \\
(32-34 \mathrm{~cm})\end{array}$ \\
\hline $\begin{array}{l}\text { Pterocanium } \\
\text { prismatium }\end{array}$ & $\begin{array}{c}5-3 \\
(20-22 \mathrm{~cm}) \\
1 \\
5, \mathrm{CC}\end{array}$ & & $\begin{array}{c}11-1 \\
(32-34 \mathrm{~cm}) \\
\vdots \\
13-4 \\
(19-21 \mathrm{~cm}) \\
\end{array}$ & & & & & & & & & & & & & \\
\hline
\end{tabular}


dary-diagnostic species to overlap in piston cores from the equatorial Pacific, in which case this zone does not exist. $S$. universus and C. tuberosa do not have overlapping stratigraphic ranges in Leg 54 recovery, however. The $N$. $r$. renilla Interval-zone was found in Holes 424, 424A, 425, and 427.

Collosphaera tuberosa Interval-zone (Nigrini, 1971)

Base - advent level of Collosphaera tuberosa (? 0.20 Ma).

Top - advent level of Collosphaera invaginata (? 0.10 Ma).

Type locality and section - unspecified.

Remarks - An age of $0.20 \mathrm{Ma}$ is provisionally adopted for the advent level of $C$. tuberosa in the absence of firm data, although the true age of this event may be somewhat older $(0.35-0.38 \mathrm{Ma}$, according to Johnson and Knoll, 1975). The C. tuberosa Intervalzone includes the first appearance of Acrosphaera lappacea, Sphaerozoum punctatum, and Tholospyris devexa finalis. This zone was recognized in Holes 419, 419A, 420, 420A, 421-423, 424B, 425, and 427.

Collosphaera invaginata Range-zone (Nigrini, 1971)

Base - advent level of Collosphaera invaginata.

Top - modern sea floor.

Type locality and section - unspecified.

Remarks - Knoll and Johnson (1975) found an age of 226,000 y. for the advent level of $C$. invaginata. This age seems to be a bit too old, purely on the basis of empirical observation of Leg 54 recovery, and an age of 100,000 y. has been provisionally assigned to this event.

\section{RADIOLARIANS AT EACH SITE}

Tables 3 and 4 give details of radiolarian distribution at each hole. Additionally, the reader is referred to the hole summary tables in the Site Reports for a comparison of all four biozonations in relation to the recovery at each site. Species frequency designations in Tables 3 and 4 follow the convention of Bjørklund and Goll (1979), and are based on slides containing approximately 25,000 to 35,000 specimens. Species represented by one to five specimens on such slides are referred to as present $(+)$; species with six to 20 specimens per slide are termed rare (R); species with 21 to 50 specimens per slide are termed common (C); species with 51 to 200 specimens per slide are termed abundant (A); species with 201 to 500 specimens per slide are termed very abundant (VA); species with more than 501 specimens per slide are termed dominant. Dashes (-) indicate that the taxon was not observed after a thorough search of one or two strewn slides. In general, only samples containing abundant, well-preserved radiolarians are listed in Tables 3 and 4, because samples containing fewer, poor-to-moderately preserved specimens provide an inaccurate impression of species ranges. Exceptions have been made in critical parts of the sediment column, however. Locations and preservation of all the radiolarian samples are indicated on the individual core description diagrams of each site.

Holes 419 and 419A (Table 3) $\left(08^{\circ} 55.96^{\prime} \mathrm{N}, 1^{\circ} 5^{\circ} 41.17^{\prime} \mathrm{W}\right.$, depth $\left.3274 \mathrm{~m}\right)$

Only 10 of the 24 radiolarian samples from these holes are listed on Table 3. Radiolarian preservation is moderate at the sediment/basalt contact (Core 5, core catcher), largely because of the association with volcanic glass. Radiolarians are poorly preserved in Core 5 , Section 4, but well preserved higher in this core as well as in Core 4. Preservation is sporadic and generally poor-to-moderate in Cores 1-3. Both the Neosemantis hofferti and Acrosphaera trepanata zones appear to be absent between Cores 4 and 5, and $N$. hofferti n. sp., $A$. trepanata, and Conarachnium nigriniae all have advent levels in Core 4,CC. Sphaerozoum crassus appears to have an anomalous range in Hole 419 , as this species occurs continuously throughout the Siphonosphaera tene$r a$ Interval-zone in Holes 420 and 428 . The true top of the Amphispyris roggentheni Zone may occur higher than Core 4, but this species has not been observed in other Leg 54 recovery where preservation is less than good, and its absence in Core 3 may be merely a preservation effect.

Collosphaera invaginata was not observed in the recovery of either Hole 419 or $419 \mathrm{~A}$, and the Collosphaera tuberosa Interval-zone is confined to a thin surface layer of no more than 1.5-meter thickness. The presence of brown clay in the top of Hole 419, Core 2 is an indication that this is the true surface sediment layer as opposed to the sediment in Core 1 . The absence of $C$. tuberosa in lower samples from Core 2 may be due to deteriorating preservation. The absence of delicate species such as Acrosphaera lappacea, Androspyris huxleyi, and Tholospyris devexa finalis in Hole 419A recovery is an additional indication of faunal thinning by selective dissolution.

\section{Holes 420 and $420 \mathrm{~A}$ (Table 3 ) \\ $\left(09^{\circ} 00.10^{\prime} \mathrm{N}, 106^{\circ} 06.77^{\prime} \mathrm{W}\right.$, depth $\left.3381 \mathrm{~m}\right)$}

Only 31 of the 86 radiolarian samples from these holes are listed in Table 3. Many samples with wellpreserved radiolarians were excluded from this table because of the essential uniformity of the fauna and species frequencies. Radiolarian preservation is poor-tomoderate in Core 13 and in the lower part of Core 12, but preservation improves considerably higher in the sediment column and is generally good from Core 4 to Core 12, Section 5. This improved preservation is apparently the result of the simultaneous occurrence of discrete volcanic ash and diatomite layers in this interval. Significant concentrations of volcanic glass were observed in Core 11, Section 2 and Core 12, Section 1. Diatomites occur in Core 6, Section 1; Core 7, Sections 5 and 6; Core 8, Sections 1-3; and Core 9, Sections 1 and 3. Radiolarian preservation is good in Core 1 but fluctuates broadly in Cores 2 and 3 , and preservation is generally poor in both cores.

Hole 420 has been used as the reference section for Leg 54 radiolarians as well as the other microfossil groups, and recovery from this hole has been designated as the type sections of five of the seven new zones. Consequently, stratigraphic ranges of individual species are regarded as typical for the eastern equatorial Pacific, with two exceptions. Cores 1-3 contain similar lithologic successions, and it is possible that the same surface layer was penetrated in all three cores. The latter eventuality would explain the unusually thick Collosphaera tuberosa Interval-zone in this recovery, where the immediately older Nephrospyris renilla renilla Interval Zone cannot be recognized because of poor preservation but cannot occupy more than 4.5 meters in the 
TABLE 3

Ranges and Frequency of Occurrence of Selected Radiolarians in Holes 419, 419A, 420, 420A, 421-423, and 427-428 from the EPR

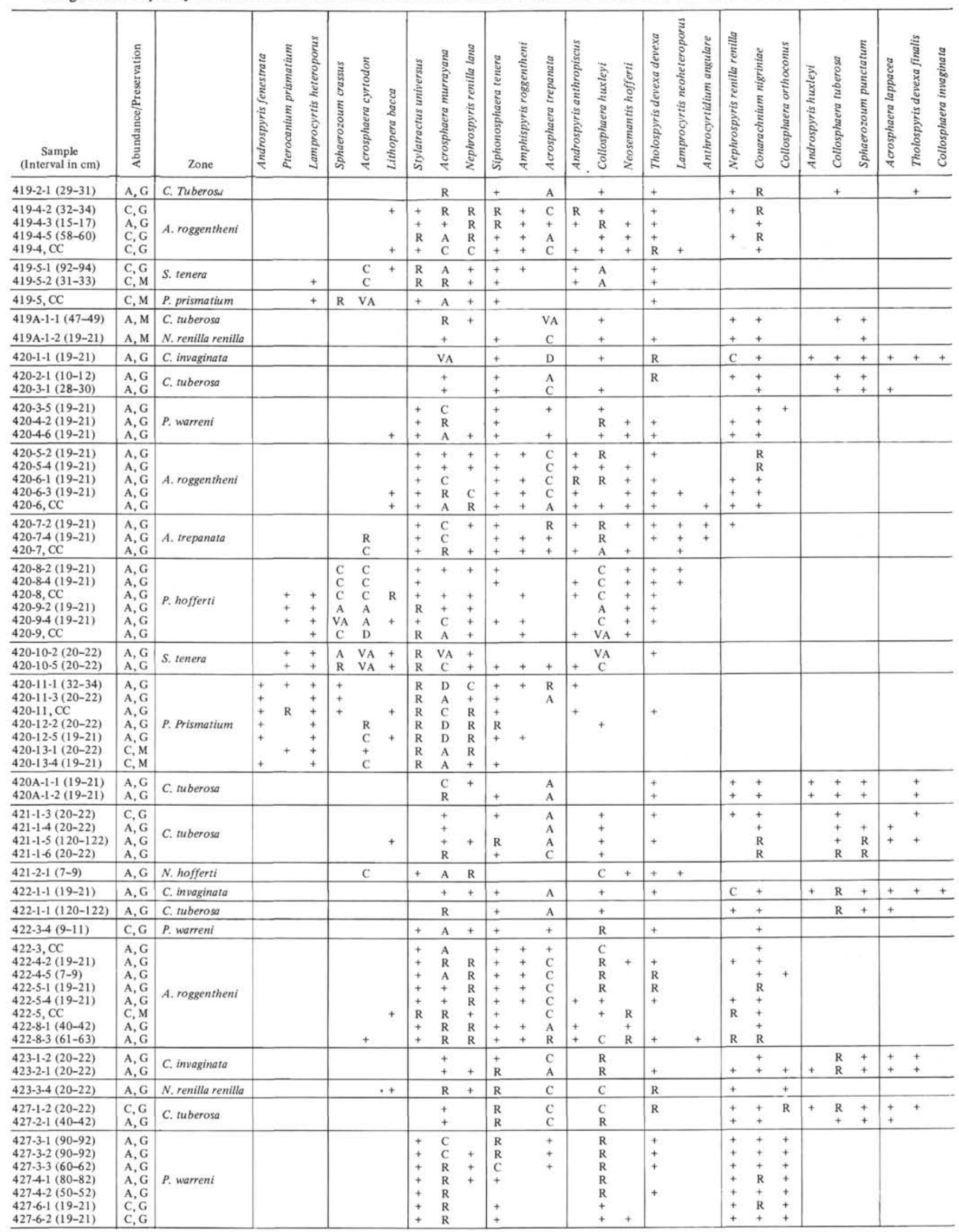


TABLE 3 - Continued

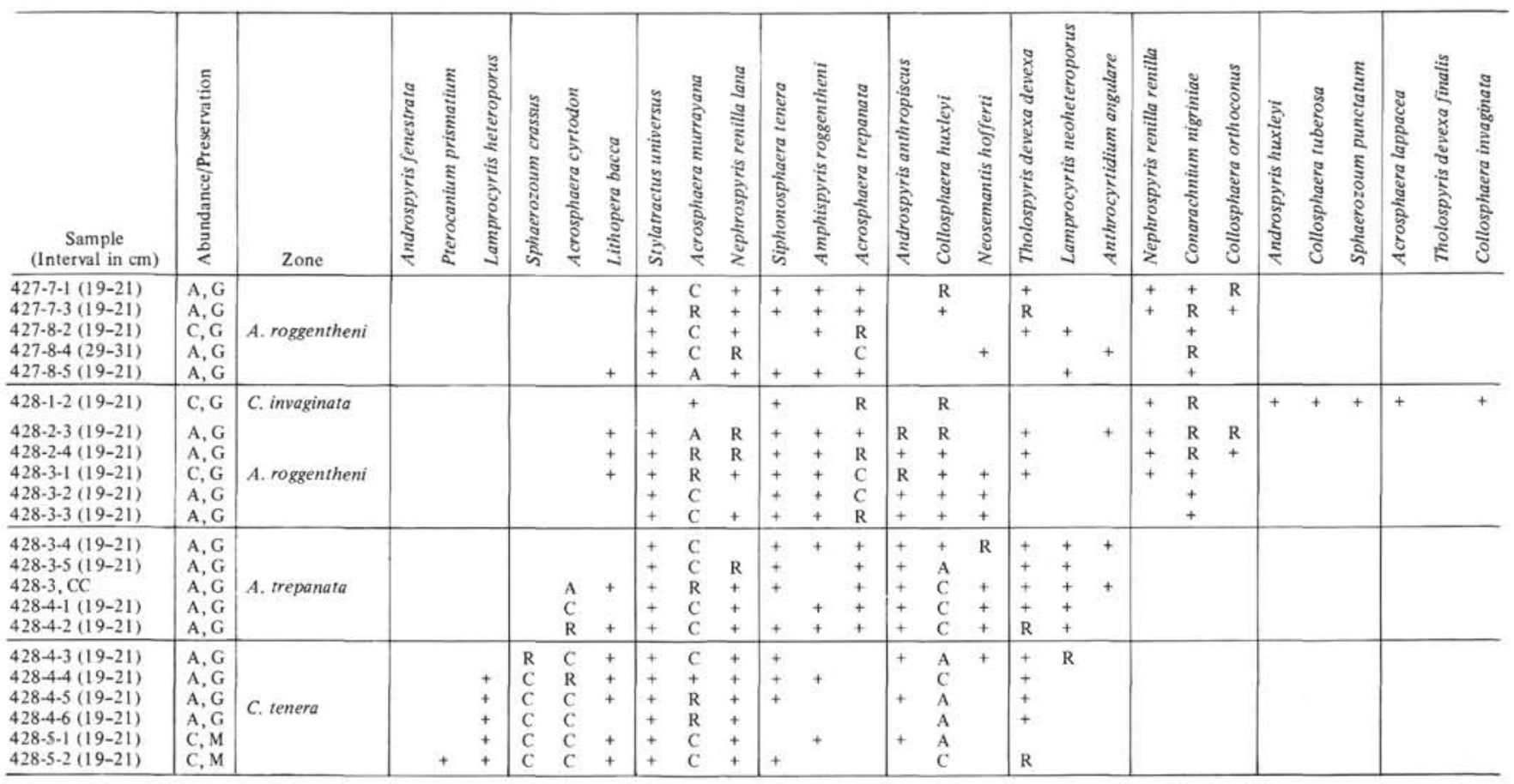

middle of Core 3. The occurrence of $C$. tuberosa is not continuous throughout Cores 1-3, because radiolarians are well preserved only in the tops of each core. Collosphaera invaginata occurs only in Core 1, however. Second, Collosphaera orthoconus has a very sporadic occurrence at Hole 420 , being present in trace frequencies only in Samples 3-5, 19-21 cm and 5-3, 19-21 cm.

\section{Hole 421 (Table 3)}

$\left(09^{\circ} 01.41^{\prime} \mathrm{N}, 106^{\circ} 03.68^{\prime} \mathrm{W}\right.$, depth $\left.3339 \mathrm{~m}\right)$

Five of the eight samples from this hole are listed on Table 3. Sediments were cored in this hole only at the mudline and at the sediment/basalt contact. The absence of Collosphaera invaginata in the top of Core 1 suggests that modern sediments were not sampled here. There is disagreement concerning the age of the sediments directly overlying basalt. The calcareous nannofossil flora indicates an age of ca. 2.1 m.y., but the ooze contains a lower Pleistocene radiolarian assemblage that includes both Neosemantis hofferti $\mathrm{n}$. $\mathrm{sp}$. and common Collosphaera huxleyi. Clearly, mechanical displacement of sediment by drilling operations or natural reworking has mixed the microfossil assemblage somewhat.

\section{Hole 422 (Table 3) \\ $\left(09^{\circ} 10.59^{\prime} \mathrm{N}, 105^{\circ} 16.27^{\prime} \mathrm{W}\right.$, depth $\left.3247 \mathrm{~m}\right)$}

Radiolarian preservation is generally good in the top of Core 1 and in Cores 4-8, but it is moderate-to-poor in Cores 2 and 3 and the lower part of Core 1. The Amphispyris roggentheni Zone is quite thick here, and the true top of this zone may extend even higher than Sample 3,CC. The absence of $A$. roggentheni $\mathrm{n}$. sp. higher in Core 3 may be a result of the decreasing quality of opal preservation in this core. Nevertheless, Stylatractus universus can be traced to Core 3, Section 4, and Sections 4 and 5 of this core are questionably assigned to the Pseudocubus warreni Interval-zone.

\section{Hole 423 (Table 3)}

$\left(09^{\circ} 08.81^{\prime} \mathrm{N}, 105^{\circ} 06.57^{\prime} \mathrm{W}\right.$, depth $\left.3161 \mathrm{~m}\right)$

Only three of the 21 samples from this hole are listed in Table 3. With the exceptions of Core 1 and the top of Core 2, radiolarian preservation is poorer here than at any of the other EPR sites. The unusually thick $\mathrm{Col}$ losphaera invaginata Range-zone $(4.5 \mathrm{~m})$ may be a result of multiple penetration of the surface layer in Cores 1 and 2, similar to the situation proposed at Hole 420. The lower half of Core 4 and Core 5 are assigned to the Amphispyris roggentheni Zone without conviction, because only one specimen of $A$. roggentheni $\mathrm{n}$. sp. was found in a single sample (Sample 5-4, 25-27 cm), but its absence higher in the section may be a preservation effect.

\section{Hole 424, 424A, 424B, and 424C (Table 4) $\left(00^{\circ} 35.33^{\prime} \mathrm{N}-00^{\circ} 35.93^{\prime} \mathrm{N}, 8^{\circ} 07.82^{\prime} \mathrm{W}\right.$, depth 2685-2705 m)}

Only 14 of the 61 samples from Site 424 are listed in Table 4. Radiolarian preservation has been adversely affected by hydrothermal activity. The mudline core at Hole $424 \mathrm{C}$, on the margin of the mounds area, contains a normal late Pleistocene succession of pelagic ooze with well-preserved radiolarians. Dating the hydrothermal event in the mounds area is difficult because of the general poor preservation and mechanical disturbance of the sediments. Yet, by piecing together the evidence from the three mounds holes, it is apparent that the hydrothermal activity occurred within the Nephrospyris renilla renilla and Collosphaera tuberosa Interval-zones (0.1-0.4 Ma). 
TABLE 4

Ranges and Frequency of Occurrence of Selected Radiolarians in Holes 424, 424A, 424B, 424C, and 425 from the GSC

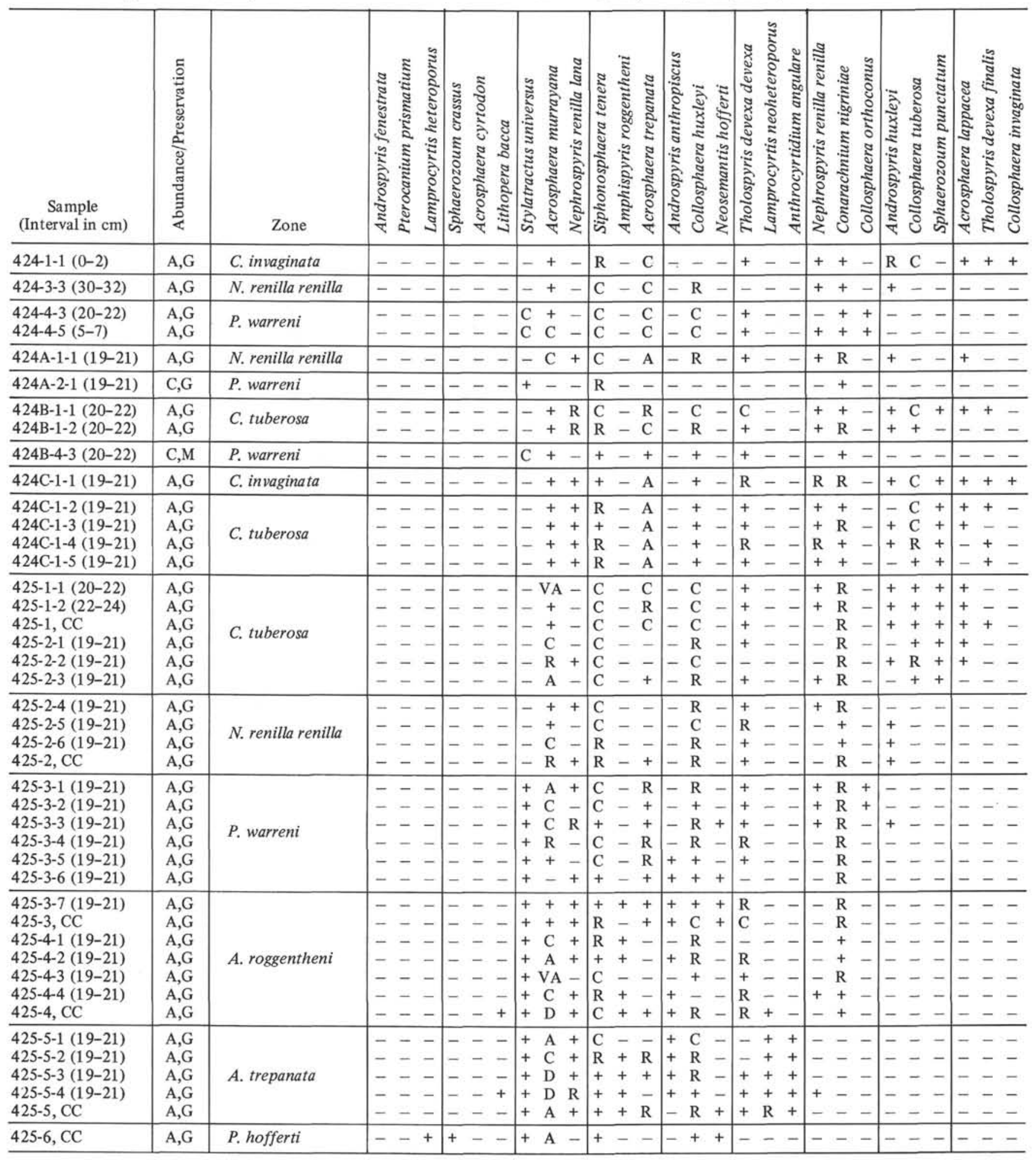

\section{Hole 425 (Table 4) $\left(01^{\circ} 23.68^{\prime} \mathrm{N}, 86^{\circ} 04.22^{\prime} \mathrm{W}\right.$, depth $\left.2850 \mathrm{~m}\right)$}

All of the samples from Hole 425 are listed in Table 4. If this sedimentary section had been cored continuously, it would have been an excellent reference stan- dard for the eastern equatorial Pacific, because of the remarkable preservation of both calcareous and siliceous microfossils and the relatively uniform sedimentation. The Collosphaera invaginata Range-zone was not recognized here. The assignment of Sample 6,CC to the Neosemantis hofferti Zone is not in good agreement 
with the slightly older ages determined by other microfossils. However, both Neosemantis hofferti and Collosphaera huxleyi occur in this sample only in trace frequencies, and it is unclear whether the Collosphaera huxleyi Interval-zone and its subzones can be used in this purely equatorial province.

\section{Hole 427 (Table 3) \\ $\left(08^{\circ} 06.79^{\prime} \mathrm{N}, 104^{\circ} 36.35^{\prime} \mathrm{W}\right.$, depth $\left.3834 \mathrm{~m}\right)$}

Only 14 of the 35 samples from Hole 427 are listed in Table 3. Radiolarian preservation is generally good in Cores 3-8, but preservation is poor below the diatomaceous beds in Cores 4 and 6. The Amphispyris roggentheni and the Pseudocubus warreni zones are quite thick here, and sedimentation between 0.4 and $1.1 \mathrm{Ma}$ was more rapid than at any of the other Leg 54 sites.

\section{Site 428 (Table 3) \\ $\left(09^{\circ} 02.77^{\prime} \mathrm{N}, 105^{\circ} 26.14^{\prime} \mathrm{W}\right.$, depth $\left.3295 \mathrm{~m}\right)$}

Only 17 of the 27 radiolarian samples from Site 428 are listed in Table 3. Radiolarian preservation is poor to moderate in Core 1 and the top of Core 2, but otherwise preservation is good in the cored intervals. The lower part of the sediment column appears to have been condensed by one or more diastems. The Neosemantis hofferti Concurrent range-zone is missing from Core 4 , and the Emiliamia annulus Zone (calcareous nannofossils) is missing from Core 5. Unfortunately, there is poor agreement as to the age and duration of these missing sediments. The stratigraphic ranges of the tabulated species are otherwise consistent with the sediment column at Hole 420.

\section{Holes 429 and 429A \\ $\left(09^{\circ} 02.01^{\prime} \mathrm{N}, 106^{\circ} 46.35^{\prime} \mathrm{W}\right.$, depth $\left.3406 \mathrm{~m}\right)$}

None of the five radiolarian samples from Site 429 have been tabulated. Only a mudline core was taken at Hole 429, and radiolarians are so few in this sediment that a zonal assignment could not be determined. Coring did not commence in Hole 429A until basalt was reached, but the upper $40 \mathrm{~cm}$ of Core 1 consists of marly nannofossil ooze with volcanic glass and a few moderately preserved radiolarians. This sparse assemblage includes Collosphaera huxleyi, Acrosphaera cyrtodon, Acrosphaera murrayana, and Androspyris anthropiscus, which should be assigned to the Siphonosphaera tenera Interval-zone or perhaps slightly higher. The nannofossil flora indicates a Pliocene age, however.

\section{EVOLUTIONARY LINEAGES}

Of the 28 radiolarians that are discussed in this chapter, two species are long-ranging taxa that are designated as the nominate species of interval zones: Plagiacantha warreni $\mathrm{n} . \mathrm{sp}$. and Siphonosphaera tenera. These species in themselves have no biostratigraphic value during late Pliocene-Pleistocene time. Eight other species, shown on the right side of Figure 2, have advent or extinction levels that are useful biostratigraphic indices in the Leg 54 recovery. Seventeen species are arranged in six tentative or well-confirmed lineages that can be traced with varying precision, because the Leg 54 recovery appears to be located at the periphery of many species distribution provinces. Both Androspyris fenestrata and Lithopera bacca are extant species that undergo zoogeographic disappearances in Leg 54 recovery.

\section{Androspyris fenestrata $\rightarrow$ Androspyris anthropiscus $\rightarrow$ Androspyris huxleyi}

This is an interesting lineage that deserves more detailed attention. The two transition events appear to be abrupt, although the three isospecies (successive morphs within a continuous lineage) have only trace occurrences in Leg 54 recovery. A. fenestrata is probably related to the Miocene spyroid Tholospyris cortinisca. There is a significant increase in skeletal size within this Pliocene/Pleistocene lineage. A. fenestrata gives rise to $A$. anthropiscus by the development of additional lattice surrounding the front and back of the sagittal ring and the basal ring. This transition occurs at or near the base of the Siphonosphaera tenera Interval-zone. A. anthropiscus has broad, thick lattice bars with beveled edges around lattice pores (Plate 4, Figures 2 and 3). The $A$. anthropiscus $\rightarrow A$. huxleyi transition occurs at about $0.5 \mathrm{Ma}$ and results in a more delicate lattice composition (Plate 4, Figures 4 and 5). A. fenestrata appears to have been completely displaced from the eastern equatorial Pacific by this descendant lineage.

\section{Lamprocyrtis heteroporus $\rightarrow$ Lamprocyrtis neoheteroporus $\rightarrow$ Conarachnium nigriniae}

This evolution has been described by Kling (1973). As with Androspyris, the stratigraphic ranges of the individual isospecies show little overlap. All three species are scarce in Leg 54 recovery, but they are consistently present and can be used as biostratigraphic indices. The $L$. heteroporus $\rightarrow L$. neoheteroporus transition occurs at about 1.3 Ma at Site 428 (base of the Acrosphaera trepanata Interval Zone) and at approximately $1.5 \mathrm{Ma}$ at Hole 420 (middle of the Neosemantis hofferti Concurrent range-zone).

\section{Nephrospyris renilla lana $\mathbf{n}$. subsp. $\rightarrow$ Nephrospyris renilla renilla}

This distinctive lineage undergoes an obvious skeletal modification in the mid to late Pleistocene, but the transformation is gradual, and the two subspecies overlap broadly both in province and in stratigraphic range. All specimens of $N$. renilla in Pliocene and early Pleistocene sediments bear secondary lattice plates covering the front and back of the sagittal ring (N. renilla lana $\mathrm{n}$. subsp., Plate 5, Figure 1). Most modern specimens have lost these lattice plates, and there is no evidence of secondary lattice development around the two pairs of large pores on the front and back of the sagittal ring $(N$. renilla renilla, Plate 5 , Figure 2 ). Both subspecies are generally scarce, and the descendant morph has a sporadic occurrence in Leg 54 recovery. $N$. renilla lana $\mathrm{n}$. subsp. disappears as early as the Pseudocubus warreni Interval Zone at Holes 420 and 427, but this morph persists into the Collosphaera invaginata Range Zone at Holes 422 and $424 C$. 


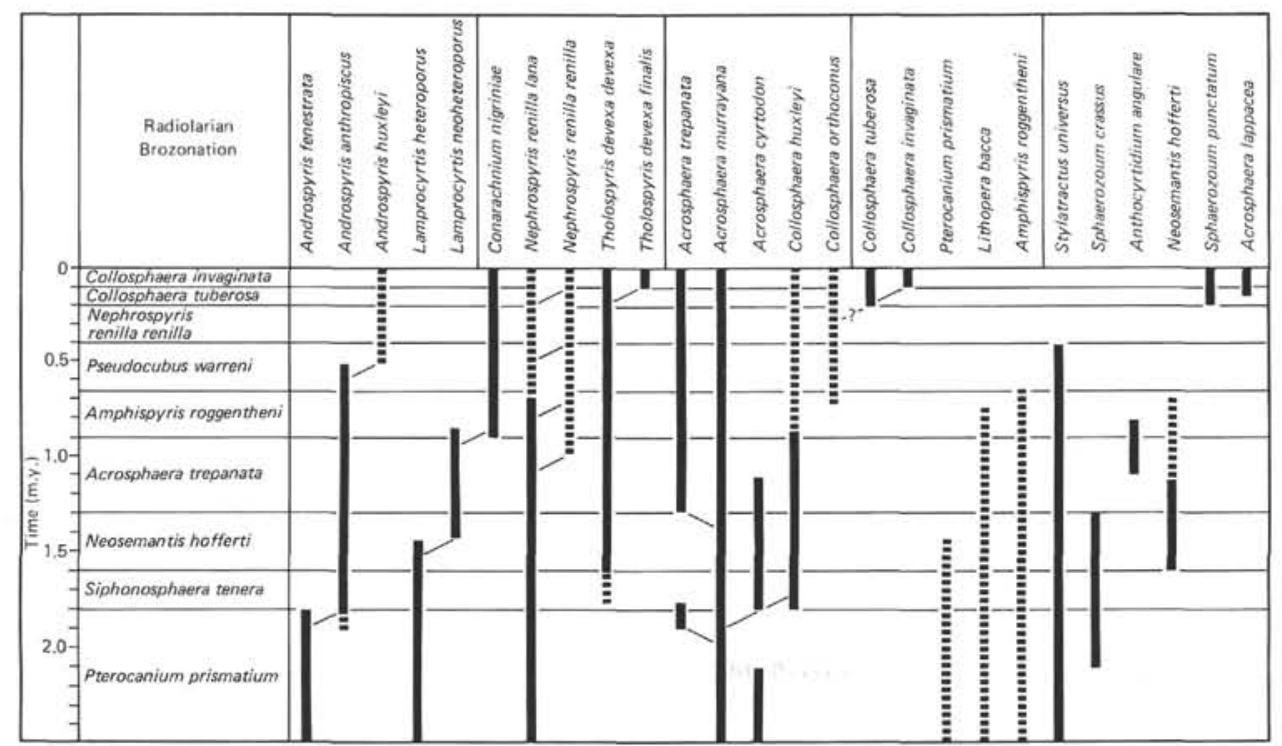

Figure 2. Lineages and stratigraphic ranges of some of the radiolarians from the East Pacific Rise and Galapagos Spreading Center.

\section{Tholospyris devexa devexa $\rightarrow$ Tholospyris devexa finalis}

This evolution was described by Goll (1972). The precursor to $T$. $d$. devexa was not observed, and $T$. $d$. finalis is too scarce in this recovery to be useful biostratigraphically.

\section{Acrosphaera murrayana $\rightarrow$ Collosphaera huxleyi}

This lineage includes some of the most common species in the EPR recovery, but the evolution is not a simple isospecies series as described here. A. murrayan$a$, whose range extends down to the lower Miocene, appears to be the ancestor to these Pliocene/Pleistocene collosphaerids. In Leg 54 sediments, $A$. murrayana is typically thick-walled, with small round pores surrounded by coronas of short spines (Plate 2, Figures 3-5). This stock undergoes two opposite evolutionary trends involving either reduction or expansion of the coronal spines. These skeletal modifications do not take place simultaneously, but alternate sequentially. In the oldest EPR recovery, A. murrayana is associated with Acrosphaera cyrtodon, which is characterized by the presence of only a single lattice spine on the margin of each lattice pore. This morph disappears in the latest Pliocene and is followed by the advent of Acrosphaera trepanata, which differs from $A$. murrayana in that the spine coronas coalesce proximally into short imperforate tubes with serrate distal edges. A. trepanata occurs only briefly in the uppermost Pliocene. The reappearance of $A$. cyrtodon at the base of the Pleistocene is associated with the advent of $C$. huxleyi, which bears no trace of lattice spines. Specimens of $C$. huxleyi in the $C$. huxleyi Interval-zone are large and thick-walled, and they share these skeletal characteristics with $A$. murrayana and $A$. cyrtodon. This species is much less abundant in the $C$. nigriniae Range-zone, and specimens have smaller, more delicate skeletons. A. trepanata reappears in the upper $C$. huxleyi Interval Zone and varies widely in abundance in the $C$. nigriniae Range Zone.

\section{Collosphaera orthoconus $\rightarrow$ Collosphaera tuberoso $\rightarrow$ Collosphaera invaginata}

The evolution of these species is unclear at the present time and may prove to be different from what has been indicated previously in this paper. Knoll and Johnson (1975) found a somewhat different distribution of these three species in piston cores from the equatorial Pacific. Collosphaera orthoconus (their Collosphaera sp. A) was restricted to the base of the stratigraphic range of $C$. tuberosa and was immediately superseded by $C$. invaginata. They concluded from this distribution as well as certain morphological intergradation that $C$. orthoconus was the precursor to $C$. invaginata. In other piston cores, the stratigraphic range of $C$. orthoconus was found to extend back to $0.60-0.65 \mathrm{Ma}$ (Johnson and Knoll, 1975). This latter observation is in better agreement with the distribution of $C$. orthoconus in Leg 54 recovery. $C$. orthoconus is older than both $C$. huxleyi and $C$. invaginata at most of the Leg 54 sites, and its stratigraphic range is restricted to the Pseudocubus warreni Interval-zone and the Amphispyris roggentheni Concurrent range-zone. $C$. orthoconus ranges higher into the $C$. tuberosa Interval-zone only at Hole 427. Its relationship to other Pleistocene Collosphaera requires additional investigation.

\section{SPECIES LIST}

Five of the 28 taxa discussed in this chapter are new species or subspecies, and they receive formal systematic treatment in the following section. Other species are listed alphabetically with a literature reference and remarks concerning morphology and distribution in Leg 54 recovery. In some cases, generic assignments are new combinations, and the binomen of the original author is indicated parenthetically.

Acrosphaera cyrtodon (Odontosphaera cyrtodon Haeckel, 1887) (Plate 2, Figures 1-2)

Remarks: Strelkov and Reshetnjak (1971) report $A$. cyrtodon in the modern plankton of the equatorial Atlantic and Indian oceans. 
The morph that I refer to as $A$. cyrtodon does not occur in the Conarachnium nigriniae Range-zone of the Leg 54 sediments. Possibly, this is another example of shifting zoogeographic provinces, such as those of Androspyris fenestrata and Lithopera bacca, but it is equally possible that the Leg 54 morph is not Haeckel's species and should be described under a new name. Specimens from Leg 54 recovery differ from Haeckel's illustration in that the large tooth or spine on the margin of the lattice pores lies in the plane of the lattice shell rather than projecting subradially.

Occurrences: Pliocene (Pterocanium prismatium Interval-zone) to lower Pleistocene (Acrosphaera trepanata Interval-zone) in the EPR sites. This species was not observed at Site 424 or Hole $425 \mathrm{C}$.

\section{Acrosphaera lappacea (Xanthiosphaera lappacea Haeckel, 1887)} (Plate 1, Figure 18)

Remarks: This species may prove to be a useful biostratigraphic index for the late Pleistocene when its advent level is more accurately known.

Occurrences: $A$. lappacea is restricted to the Collosphaera tuberosa and Collosphaera invaginata zones at all of the Leg 54 sites.

Acrosphaera murrayana (Choenicosphaera murrayana Haeckel, 1887) (Plate 2, Figures 3-5)

Remarks: I have applied this name to collosphaerids with a corona of short spines surrounding the lattice pores, but no tubes.

Occurrences: This extant species ranges throughout the Leg 54 recovery, but its frequency of occurrence is quite erratic. At Hole 420, A. murrayana is common to dominant in the Pterocanium prismatium and Siphonosphaera tenera Interval-zones, but its frequency decreases markedly in the Neosemantis hofferti Concurrent range-zone, and $A$. murrayana undergoes minor oscillations in frequency in the Conarachnium nigriniae Range-zone.

\section{Acrosphaera trepanata (Trypanosphaera trepanata Haeckel, 1887)}

$$
\text { (Plate 2, Figures 6-9) }
$$

Remarks: This name is applied only to specimens that bear a short flange-like tube surrounding the lattice pores.

Occurrences: This species has a discontinuous range at Hole 420. It occurs in trace-to-abundant frequencies in the latest Pliocene and lower Siphonosphaera tenera Interval-zone, but disappears for approximately 0.5 m.y. within the Collosphaera huxleyi Interval-zone. After its reappearance at about $1.3 \mathrm{Ma}, A$. trepanata has a somewhat sporadic and variable occurrence, but the species is abundant to dominant in the Collosphaera tuberosa and Collosphaera invaginata zones.

\section{Androspyris anthropiscus Haeckel, 1887}

(Plate 4, Figures 2-3)

Remarks: This species represents the initiation of an evolutionary trend towards increased skeletal size and increased lattice formation, such that the basal pores and sagittal lattice pores become overlatticed.

Occurrences: The zoogeographic province of both $A$. anthropiscus and Androspyris huxleyi is restricted to a small region of the eastern equatorial Pacific, and all the Leg 54 sites lie on the margin of this range. The advent level of $A$. anthropiscus is approximately at the base of the Collosphaera huxleyi Interval-zone, and its extinction level occurs at about $0.5 \mathrm{Ma}$. This species has a sporadic occurrence in trace frequencies at Holes $419,420,422,425$, and Site 428 , and it was not observed at Hole 427.

\section{Androspyris fenestrata (Tholospyris fenestrata Haeckel, 1887)}

$$
\text { (Plate 4, Figure 1) }
$$

Remarks: This species is the precursor to Androspyris anthropiscus and probably descended from Tholospyris cortinisca. A. fenestra$t a$ occurs in the modern plankton of central water masses, but is not found in Pleistocene equatorial sediments.

Occurrences: $A$. fenestrata was observed only in the Pterocanium prismatium Interval-zone of Hole 420.

\section{Androspyris huxleyi (Lamprospyris huxleyi Haeckel, 1887)}

(Plate 4, Figures 4-5)

Remarks - A. huxleyi differs from $A$. anthropiscus in its much more delicate lattice construction and open basal aperture.

Occurrences - This species is represented only by sporadic specimens in the Collosphaera tuberosa and Collosphaera invaginata zones of the EPR sites. Its range extends back to the Pseudocubus warreni Interval-zone at Hole 425.

\section{Anthocyrtidium angulare Nigrini, 1971}

(Plate 3, Figure 9)

Remarks: The sharp break of the thoracic margin, diagnostic for this species, is imperfectly developed on Leg 54 specimens, and perhaps I have applied this name improperly.

Occurrences: This species is very scarce in the EPR sites, and its stratigraphic range is atypically short, being restricted to the upper Acrosphaera trepanata Interval-zone and the lower Amphispyris roggentheni Concurrent range-zone. $A$. angulare has a more consistent occurrence at Hole 425 , but the sediment column there is too young to include its entire stratigraphic range.

\section{Collosphaera huxleyi Müller, 1855}

(Plate 1, Figures 16-17)

Remarks: There is some doubt whether the lower Pleistocene morph is properly identified as Collosphaera huxleyi. In Leg 54 recovery, this species is larger and more thick-walled than $C$. huxleyi of the modern plankton. The "heavy" morph is common in the Collosphaera huxleyi Interval-zone of the EPR sites, but it disappears at approximately the base of the Conarachnium nigriniae Range-zone. Smaller, more delicate specimens of similar morphology occur in lower frequencies in the $C$. nigriniae Range-zone, but the evolution of these collosphaerids may be more complex than is presently understood.

Occurrences: This species occurs throughout the Pleistocene in all of the Leg 54 sites.

\section{Collosphaera invaginata (Buccinosphaera invaginata Haeckel, 1887)} (Plate 1, Figures 14-15)

Remarks: Bjørklund and Goll (1979) synonymized Buccinosphaera with Collosphaera.

Occurrences: This species was observed in trace frequencies in the uppermost 1-3 meters of the sediment column in Holes 420, 422-424, $424 \mathrm{C}$, and 428 .

Collosphaera orthoconus (Conosphaera orthoconus Haeckel, 1887) (Plate 1, Figures 10-11)

Remarks: This is the species referred to as Collosphaera sp. A by Knoll and Johnson (1975). Its taxonomy is treated briefly by Bjørklund and Goll (1979).

Occurrences: $C$. orthoconus has a relatively consistent occurrence in trace frequencies at Hole 427 from the Amphispyris roggentheni to the Collosphaera tuberosa Interval-zones, but this species is restricted to sporadic occurrences at the other Leg 54 sites.

\section{Collosphaera tuberosa Haeckel, 1887}

(Plate 1, Figures 12-13) 429.

Occurrences: $C$. tuberosa occurs in all the Leg 54 sites, except Site

\section{Conarachnium nigriniae Caulet, 1971}

(Plate 3, Figure 10)

Remarks: Kling (1973) named this species Lamprocyrtis haysi.

Occurrences: $C$. nigriniae has a consistent occurrence in trace-torare frequencies at all of the Leg 54 sites, except Site 429.

\section{Lamprocyrtis heteroporus (Lamprocyclas heteroporus Hays, 1965)} (Plate 3, Figures 12-13)

Occurrences: Kling (1973) reported the range of this species from basal Pliocene to approximately 1.4 Ma. Its advent level is below the oldest sediments recovered on Leg 54, but its extinction level appears to be essentially isochronous in the equatorial and North Pacific. This species occurs in trace frequencies at Holes 419, 420, 425, and Site 428.

\section{Lamprocyrtis neoheteroporus Kling, 1973}

(Plate 3, Figure 11)

Occurrences: The extinction level of $L$. neoheteroporus occurs somewhat earlier in Leg 54 sediments than Kling (1973) reported for the North Pacific. This species is present in trace frequencies at Holes 419-421, 425, 427, and Site 428. 


\section{Lithopera bacca Ehrenberg, 1872}

(Plate 3, Figure 8)

Remarks: This extant species occurs in the modern plankton of the central water masses.

Occurrences: $L$. bacca occurs sporadically in trace frequencies in sediments ranging from the Pterocanium prismatium to the Amphispyris roggentheni Interval zones at Holes 419-423, 425, 427, and Site 428.

\section{Nephrospyris renilla renilla Haeckel, 1887}

(Plate 5, Figure 2)

Remarks: $N$. r. renilla can be distinguished easily from Nephrospyris renilla lana $\mathrm{n}$. subsp. by the absence of secondary lattice plates on the front and back of the skeleton.

Occurrences: This extant subspecies has a relatively consistent occurrence at Hole 427, with an advent level in the upper Amphispyris roggentheni Interval-zone. At all the other Leg 54 sites, $N$. $r$. renilla has a sporadic occurrence commencing somewhat earlier in the Acrosphaera trepanata Interval-zone at Hole 420.

\section{Pterocanium prismatium Riedel, 1957}

(Plate 3, Figure 4)

Occurrences: This species was observed only at Hole 420 and Site 428 , where it is present sporadically in sediments as young as the middle Neosemantis hofferti Concurrent range-zone.

\section{Siphonosphaera tenera Brandt, 1885}

(Plate 1, Figures 6-9)

Occurrences: This long-ranging species is present relatively consistently in trace frequencies at the EPR sites and rare-to-common at Site 424 and Hole 425.

\section{Sphaerozoum punctatum Müller, 1858}

(Plate 1, Figures 1-2)

Remarks: This species is distinguished from other Sphaerozoum by the elaboration of minute secondary spines.

Occurrences: $S$. punctatum occurs in trace frequencies in the Collosphaera tuberosa and Collosphaera invaginata zones of all the Leg 54 holes, except Holes 424, 424A, and 429.

\section{Stylatractus universus Hays, 1970 (Plate 3, Figure 7)}

Occurrences: The advent level of this species is below the oldest sediment penetrated on Leg 54. S. universus is consistently present in trace-to-rare frequencies in all of the Leg 54 holes, except Holes 423 and $424 \mathrm{C}$. Its extinction level marks the top of the Pseudocubus warreni Interval-zone.

\section{Tholospyris devexa devexa Goll (1969)}

(Plate 7, Figures 3, 5, 7)

Occurrences: This species has a relatively consistent occurrence throughout the Pleistocene in all the Leg 54 sites, except Site 429.

\section{Tholospyris devexa finalis Goll, 1972 \\ (Plate 7, Figures 1-2)}

Remarks: This subspecies is too scarce to be biostratigraphically useful in Leg 54 recovery.

Occurrences: $T . d$. finalis is sporadically present in trace frequencies in the Collosphaera tuberosa and Collosphaera invaginata zones at all the Leg 54 sites, except Sites 428 and 429.

\section{SYSTEMATICS}

\section{Order SPUMELLARIA Ehrenberg, 1875 \\ Family SPHAEROZOIDAE Müller, 1858 \\ Genus SPHAEROZOUM Meyen, 1834 \\ Sphaerozoum crassus Goll, n. sp. \\ (Plate 1, Figures 3-5)}

Diagnosis: A species of Sphaerozoum characterized by its small stout size and micronodular surface texture.

Name: crassus (Latin) - thick.

Description: Axial rod 42-65 m long, 8-12 $\mathrm{m}$ in diameter, circular in cross section. Two to four simple spines, approximately equal in length to the axial rod, radiate in equi-angular clusters from each end of the axial rod. All surfaces of the axial rod and spines bear a profusion of minute spines or nodes.

Remarks: There is a trend in this species towards increasing thickness of the skeletal elements with time. Skeletons of the oldest specimens are slender and are distinguished from other sphaeroids by their micronodular texture. In addition to being thick-walled, the peripheries of the skeletal elements of younger specimens have a double image (Plate 1, Figures 3, 4), giving the impression of being hollow. This image may result from regular arrangement of the nodes in longitudinal rows, however.

This species has an abrupt extinction level in the EPR sites. Other younger sphaeroids, such as Rhaphidozoum acuferum (Müller) bear spicules, but $S$. crassus n. sp. is distinguished from these species by its much smaller size.

Holotype: USNM 258902, Sample 428-4-6, 19-21 cm, England finder F31/0, Plate 1, Figure 4.

Paratypes: USNM 258903, Sample 420-10-2, 19-21 cm, England finder C38/0, Plate 1, Figure 3. USNM 258904, Sample 420-9-4, 19-21 $\mathrm{cm}$, slide 1, England finder S26/0, Plate 1, Figure 5.

Occurrences: This species was observed only at Holes 419, 420, 425 , and 428 . S. crassus n. sp. first appears in trace frequencies in the uppermost Pterocanium prismatium Interval-zone (late Pliocene), and it is common to very abundant in the Siphonosphaera tenera and Neosemantis hofferti zones. Only traces of $S$. crassus $\mathrm{n}$. sp. were found at Hole 425 , and it is uncertain whether this species had a significant occurrence in purely equatorial waters.

\section{Order NASSELLARIA Ehrenberg, 1875 \\ Superfamily PLAGIACANTHOIACEA Hertwig, 1879, emend. Goll 1979 \\ Family PLAGIACANTHOIDAE emend. Goll, 1979 \\ Genus PSEUDOCUBUS Haeckel, 1881 \\ Pseudocubus warreni Goll, n. sp. \\ (Plate 3, Figures 5-6)}

?Pseudocubus obeliscus Haeckel 1887, p. 1010, pl. 94, fig. 11.

Diagnosis: A species of Pseudocubus with spines and fine chaotic lattice surrounding the cephalic elements.

Name: In honor of Dr. Nick Warren, Institute of Geophysics and Planetary Physics, University of California, Los Angeles, California.

Description: The basic tribladed cephalic elements of $P$. warreni are similar to those of $P$. obeliscus, but additionally the skeleton includes a complex elaboration of other lattice bars and spines that anastamose distally to form an irregular external lattice shell (Plate 3, Figure 5). This lattice shell, composed of a fine lattice trellis, includes a large but irregularly framed basal aperture. Delicate lattice is not preserved on some specimens (Plate 3, Figure 6), but the major tribladed bars and spines projecting from the cephalic elements are clearly visible.

Holotype: USNM 258905, Sample 425-3-4, 19-21 cm, slide 1, England finder R57/0, Plate 3, Figure 5.

Occurrences: The advent level of this extant species is unknown but occurs below the oldest sediment recovered on Leg 54. This species is scarce to common in Hole $\mathbf{4 2 5}$ sediments, but $P$. warren $i$ is sporadically preserved in trace frequencies in EPR sediments.

Family TRISSOCYCLIDAE Haeckel, 1881, emend. Goll, 1968 Genus AMPHISPYRIS Haeckel 1881

Amphispyris roggentheni Goll, n. sp. (Plate 6, Figures 1, 3, 4; Plate 7, Figures 4, 6)

Diagnosis: A species of Amphispyris characterized by the pronounced width of the lattice shell.

Name: In honor of Dr. William Roggenthen, South Dakota School of Mines and Technology, Department of Geology, Rapid City, South Dakota, shipmate on Leg 54.

Description: With the exception of the composition and size of the lattice shell, this species is very similar to Amphispyris reticulata (Ehrenberg) 1872. Goll (1969) emended the description of $A$. reticulata (Liriospyris reticulata), and two specimens are illustrated here for comparison (Plate 6, Figures 2 and 5). The dimensions of the sagittal ring of these two species occupy the same size range, and the structural relationships of the sagittal ring and lattice shell are identical for both morphs. Lattice shells are apico-basally flattened and inflated, oblate in the front-to-back and lateral directions. When viewed from the 
apical or basal sides, the gross outline of the lattice shell is kidneyshaped, with an indentation near the vertical spine. There is no basal ring or basal aperture; the lattice shell encloses the base of the sagittal ring, and the short primary lateral spines are joined to the lattice shell. This shell has its greatest dimension in the front-to-back direction (thickness) on specimens of $A$. reticulata. The width of the lattice shell (333-440 mm) is far greater than the thickness on specimens of $A$. roggentheni, and the lattice shell may be constricted at both the front and back (Plate 6, Figure 4).

Lattice shells of both species are composed of lattice bars of two distinct sizes. Six pairs of massive lattice bars are joined to the sagittal ring, and smaller lattice bars proliferate from them to produce a delicate lattice. A few specimens of $A$. roggentheni (Plate 6, Figure 3) have a fine lattice similar to $A$. reticulata, but most specimens have a coarser lattice with pores $10-25 \mathrm{~mm}$ in diameter framed by thick lattice bars.

Remarks: Almost certainly, A. roggentheni n. sp. does not represent an isolated breeding population, and consequently it does not merit full species rank. This morph probably will be designated as a subspecies when its evolution is better understood.

Holotype: USNM 258906, Sample 428-4-4, 19-21 cm, England finder F24/4, Plate 7, Figure 6.

Paratype: USNM 248907, Sample 422-5-4, 19-21 cm, slide 2, England finder L12/1, Plate 7, Figure 4.

Occurrences: This species has a relatively consistent occurrence in trace frequencies in the Collosphaera huxleyi and Amphispyris roggentheni zones at Holes 419, 420, 422, 425, and 428. Its occurrence is more sporadic at Hole 428 , and $A$. roggentheni $\mathrm{n}$. sp. was not observed at Holes 421, 423, and Site 424.

\section{Genus NEPHROSPYRIS Haeckel, 1881}

\section{Nephrospyris renilla Haeckel, 1887}

Nephrospyris renilla lana Goll, n. subsp.

(Plate 5, Figure 1)

Nephrospyris renilla Haeckel, 1887, p. 1101 , pl. 90 , fig. 9 (not 10)

Diagnosis: A subspecies of $N$. renilla characterized by web-like developments of secondary lattice on the front and back of the lattice shell.

Name: lana (Latin) - fish net.

Description: This subspecies is similar in every respect to $N$. renilla renilla, except for the fine lattice plates, which are composed of delicate lattice bars one third to one fifth the size of the other lattice bars. These lattice plates cover the pair of large sagittal lattice pores on the front and back of the skeleton. On some specimens, these lattice plates also cover adjacent large lattice pores. Lattice plate development ranges from loose trellises to dense meshes. On old specimens, the lattice plates are joined directly to the external ridge on the front of the sagittal ring and at a point above the vertical spine on the back of the sagittal ring. Lattice plates are slightly inflated on younger specimens and extend around the outside of the sagittal ring. A single short connector bar projecting from the midpoint of the front of the sagittal ring is joined to the middle of the lattice plate of these specimens, and the back lattice plate is free of the sagittal ring.

This subspecies has a pronounced size range. The maximum width of the lattice shell varies from $290-580 \mathrm{~mm}$, based on measurements of 35 specimens from various Leg 54 samples.

Remarks: Frequently, the secondary lattice plates are not preserved, but the subspecies can be recognized by small spines (remnants of the lattice plates) around the margins of the large sagittal lattice pores. These minute simple spines lie in the plane of the lattice shell. Additionally, some specimens of $N$. $r$. lana have short stubby spines projecting from the junctures of the broad lattice bars. The precursor to $N$. r. lana occurs sporadically in the oldest Leg 54 recovery and is highly spinous. $N$. r. lana is the ancestor of $N$. r. renilla.

Holotype: USNM 258908, Sample 425-5-4, 19-21 cm, slide 1, England finder L50/2, Plate 5, Figure 1.

Occurrences: The advent level of this subspecies is below the oldest Leg 54 recovery. $N$. $r$. lana ranges at least to the Pseudocubus warreni Zone at Hole 420, and it may be extant.
Genus NEOSEMANTIS Popofsky, 1913, emend. Goll, 1979

\section{Neosemantis hofferti Goll, n. sp.}

(Plate 3, Figures 1-3)

Diagnosis: A species of Neosemantis characterized by four major, radially directed apophyses bearing regular verticils of uniformly sized spicules.

Name: In honor of Dr. Michel Hoffert, Institut de Géologie, Strasbourg, France, a shipmate on Leg 54.

Description: Skeleton consists of cephalic elements and their associated spicules; no lattice shell. Apical and two primary lateral apophyses of equal length, 95-136 $\mu \mathrm{m}$ long, 7-9 $\mu \mathrm{m}$ in diameter, distinctively tribladed in cross section. Frontal apophyse somewhat shorter, 74-98 $\mu \mathrm{m}$ long, but otherwise identical to primary lateral apophyses. All apophyses radiate from short $(10 \mu \mathrm{m})$, round median bar, which bears a small spine-like axobate (Plate 3, Figure 3). Frontal and primary lateral apophyses lie in horizontal plane with median bar. Apical apophyse is slightly arched, with convex side towards the front. Spicules $12-30 \mu \mathrm{m}$ long project radially from the three ridges along the margins of each apophyse. These spicules are arranged in sets of regular verticils consisting of three spicules and spaced at intervals of 20-30 $\mu \mathrm{m}$ along each apophyse. All specimens have a simple, well-developed vertical spine $18-32 \mu \mathrm{m}$ long, with or without a profusion of micronodes.

Remarks: $N$. hofferti n. sp. is a close homeomorph of some specimens of Neosemantis bjorklundi mimicus Goll,1979, but it is distinguished from the latter subspecies by its larger size and more slender apophyses with regularly arranged verticils composed of small spicules. $N$. hofferti $\mathrm{n}$. sp. lacks the verticil of large spicules near the end of each apophyse, which is characteristic of younger specimens of $N$. b. mimicus. The vertical spine is more prominent on specimens of $N$. hofferti than on $N$. bjorklundi. Both $N$. b. mimicus and $N$. $b$. bjorklundi have their disappearance levels below the top of the Cannartus petterssoni Zone (lower upper Miocene) in the equatorial Pacific. N. hofferti represents the iterative evolution of this morphology in the Pleistocene, possibly from a similar precursor. $N$. hofferti $\mathrm{n}$. sp. is the probable ancestor of Neosemantis cladophora, which first appears in the Pseudocubus warreni Interval-zone. $N$. cladophora is distinguished from its precursor by its upwardly arched primary lateral apophyses.

Holotype: USNM 258909, Sample 420-5, CC, slide 1, England finder W48/2, Plate 3, Figure 2.

Paratypes: USNM 258910, Sample 427-8-4, 29-31 cm, England finder V49/3, Plate 3, Figure 1. USNM 258911, Sample 428-3-4, 19-21 cm, England finder X19/1, Plate 3, Figure 3.

Occurrences: At Hole $420, N$. hofferti $\mathrm{n}$. $\mathrm{sp}$. has a relatively consistent occurrence in trace frequencies from the base of the Neosemantis hofferti Zone (1.58 Ma) to the middle of the Pseudocubus warreni Interval-zone $(0.5 \mathrm{Ma})$. The species has a more sporadic occurrence in the other Leg 54 recovery.

\section{ACKNOWLEDGMENTS}

This work was completed while the author was a fellow of the Royal Norwegian Council for Scientific and Industrial Research at the Geological Institute, University of Bergen. The article was reviewed by W. R. Riedel and A. Sanfilippo.

\section{REFERENCES}

Bjørklund, K. R., and Goll, R. M., 1979. Internal skeletal structures of Collosphaera and Trisolenia: A case of repetitive evolution in the Collosphaeridae (Radiolaria). J. Paleontol., v. 53 , p. 1293.

Brandt, K., 1885. Die koloniebildende Radiolarien (Sphaerozoëen) des Golfes von Neapel und der angrenzenden Meeresabsnitte. Eine Monographie. Fauna Flora Golf. Neapel, v. $13, \mathrm{p} 1$.

Caulet, J., 1971. Contribution à l'étude de quelques radiolaires nassellaires des boues de la Méditerranée et du Pacifique. Cahiers de Micropaléontologie, ser. 2, v. 10, p. 1. 
Chen, P.-H., 1975. Antarctic radiolaria. In. Hayes, D. E., Frakes, L. A., et al., Initial Reports of the Deep Sea Drilling Project, v. 28: Washington (U.S. Government Printing Office), p. 437.

Ehrenberg, C. G., 1872. Mikrogeologische Studien über das kleinste Leben der Meeres-Tiefgründe aller Zonen und dessen geologischen Einfluss. Kgl. Akad. Wiss. Berlin, Abh. Jahre 1872, p. 265.

1875. Fortsetzung der mikrogeologischen Studien als Gesammt Uebersicht der mikroskopischen Paläontologie gleichartig analysiter Gebirgsarten der Erde, mit specieller Rücksicht auf den Polycystinen Mergel von Barbados. Abh. Kgl. Akad. Wiss. Berlin. Jahre 1875, p. 1.

Goll, R. M., 1968. Classification and phylogeny of Cenozoic Trissocyclidae (Radiolaria) in the Pacific and Caribbean Basins. Part I. J. Paleontol., v. 42 (6), p. 1409. 1969. Classification and phylogeny of Cenozoic Trissocyclidae (Radiolaria) in the Pacific and Caribbean Basins. Part II. Ibid., v. 43 (2), p. 322. 1972. Systematics of eight Tholospyris taxa (Trissocyclidae: Radiolaria). Micropaleontology, v. 18 (4), p. 443. 1979. The Neogene evolution of Zygocircus, Neosemantis and Callimatra: their bearing on Nassellarian classification. A revision of the Plagiacanthoidea. Micropaleontology, v. 25 (3), p. 365.

Haeckel, E., 1881. Entwurf eines Radiolarien-Systens auf Grund von Studien der Challenger Radiolarien. Jena $\mathrm{Z}$. Med. $\mathrm{Na}$ turwiss., v. 15 (3), p. 418.

1887. Report on the Radiolaria collected by H. M. S. Challenger during the years 1873-76. Rept. Voyage Challenger, Zool., v. 18.

Hayes, J. D., and Shackleton, N. J., 1976. Globally synchronous extinction of the radiolarian Stylatractus universus. Geology, v. 4, p. 649.

Hays, J. D., 1965. Radiolaria and late Tertiary and Quaternary history of Antarctic Seas. Am. Geophys. Union Antarc. Res. Ser., v. 5, (125), p. 125. 1970. Stratigraphy and evolutionary trends of Radiolaria in North Pacific deep sea sediments. In Hays, J. D. (Ed.), Geological Investigations of the North Pacific: Geol. Soc. Am. Mem., v. 126, p. 185.

Hertwig, R., 1879. Der Organismus der Radiolarien: Jena (G. Fischer), p. 1.

International Subcommission on Stratigraphic Classification, 1976. International stratigraphic guide. A Guide to Strati- graphic Classification, Terminology, and Procedure: New York (Wiley-Interscience), p. 200.

Johnson, T. C., 1976. Controls on the preservation of biogenic opal in the Eastern Tropical Pacific. Science, v. 192, p. 887.

Johnson, D. A., and Knoll, A. H., 1975. Absolute ages of Quaternary radiolarian datum levels in the equatorial $\mathrm{Pa}$ cific. Quat. Res., v. 5, p. 99.

Kling, S. A., 1973. Radiolaria from the eastern North Pacific, Deep Sea Drilling Project, Leg 18. In Kulm, L. D., von Huene, R., et al., Initial Reports of the Deep Sea Drilling Project, v. 18: Washington (U.S. Government Printing Office), p. 617 .

Knoll, A. H., and Johnson, D. A., 1975. Late Pleistocene evolution of the collosphaerid radiolarian Buccinosphaera invaginata Haeckel. Micropaleontogy, v. 21 (1), p. 60.

Meyen, F. J. F., 1834. Über das Leuchten des Meeres, Bescreibung einiger Polypen und anderer niederer Thiere. Beiträge zur Zoologie, desammelt auf einer Reise um die Erde: Kaiserl. Leopold.-Carl. Akad. Naturforsch., Verh., v. 16, p. 125.

Morley, J. J., and Shackleton, N. J., 1978. Extension of the radiolarian Stylatractus universus as a biostratigraphic datum to the Atlantic Ocean. Geology, v. 6, p. 309.

Müller, J., 1855. Über die im Hafen von Messina beobachteten Polycystinen. Kgl. Preuss. Akad. Wiss. Berlin, Ber. Jahre 1855 , p. 671.

1858. Über die Thalassicollen, Polycystinen und Acanthometren des Mittelmeeres. Abh. Kgl. Akad. Wiss. Berlin, Jahre 1858, p. 1.

Nigrini, C., 1971. Radiolarian zones for the Quaternary of the equatorial Pacific Ocean. In Funnell, B. M., and Riedel, W. R. (Eds.), The Micropaleontology of Oceans: Cambridge (Cambridge University Press), p. 443.

Popofsky, A., 1913. Die Nassellarien des Warmwassergebietes. Deutsche Südpolar Exped., 1901-1903, 14, (Zool. 6), v. 6 (11), p. 217

Riedel, W. R., 1957. Radiolaria: a preliminary stratigraphy. Rept. Swed. Deep-Sea Exped., v. 6 (3), p. 59.

Riedel, W. R., and Sanfilippo, A., 1978. Stratigraphy and evolution of tropical Cenozoic radiolarians. Micropaleontology, v. 24 (1), p. 61.

Strelkov, A. A., and Reshetnjak, V. V., 1971. Kolonial Radiolarii Spumellaria Mirovogo Okeana. In Strelkov, A. A. (Ed.), Issled, Fauny morei., v. 9 (17): Leningrad (Acad. Sci. USSR, Zool. Inst.), p. 295. 
PLATE 1

All figures $\times 300$.

Scale bar equals $100 \mu \mathrm{m}$.

Figures 1, 2 Sphaerozoum punctatum

1. Oblique side view, Sample $424 \mathrm{C}-1-5,19-21 \mathrm{~cm}$, England finder X52/3.

2. Oblique end view, Sample 425-1-1, 20-22 cm, S1.1, England finder C27/3.

Figures 3-5 Sphaerozoum crassus Goll n. sp.

3. End view, Sample 420-10-2, 19-21 cm, S1.1, England finder C38/0, Paratype USNM 258903.

4. Oblique end view, Sample 428-4-6, 19-21 cm, England finder F21/0, Holotype 258902.

5. Side view, Sample 420-9-4, 19-21 cm, S1.1, England finder S26/0, Paratype USNM 258904.

Figures 6-9 Siphonosphaera tenera

6. Sample 427-7-3, 19-21 cm, England finder R8/0.

7. Sample 425-4-2, 19-21 cm, S1.2, England finder $\mathrm{Q} 8 / 0$.

8. Sample 428-1-2, 19-21 cm, England finder C41/4.

9. Sample 427-7-3, 19-21 cm, England finder F11/0.

Figures 10, 11 Collosphaera orthoconus

10. Sample 427-1-2, 20-22 cm, England finder O38/0.

11. Sample 423-3-4, 20-22 cm, S1.1, England finder $\mathrm{T} 30 / 4$.

Figures 12, 13 Collosphaera tuberosa

12. Sample 424C-1-5, 19-21 cm, England finder L39/3.

13. Sample 424B-1-1, 20-22 cm, England finder X16/0.

Figures 14, 15 Collosphaera invaginata

14. Focused on internal spines and tubes, Sample 420$1-1,19-21 \mathrm{~cm}, \mathrm{~S} 1.1$, England finder E21/2.

15. Same specimen, focused on upper surface.

Figures 16, 17 Collosphaera huxleyi

16. Sample 428-3,CC, England finder X41/2.

17. Sample 428-3,CC, England finder R23/2.

Figure 18 Acrosphaera lappacea

Sample 424C-1-3, England finder X35/0. 
PLATE 1
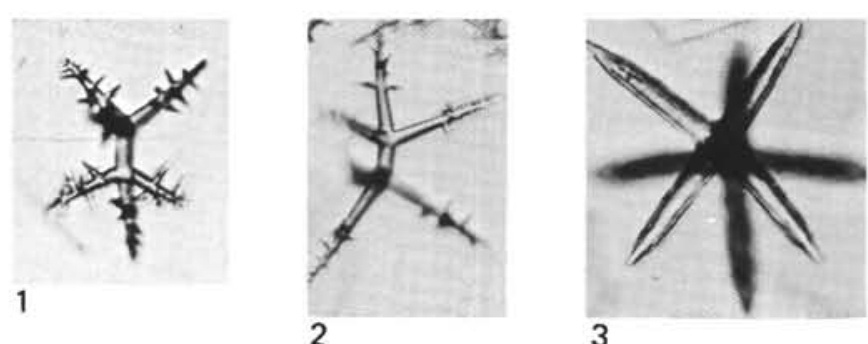

3
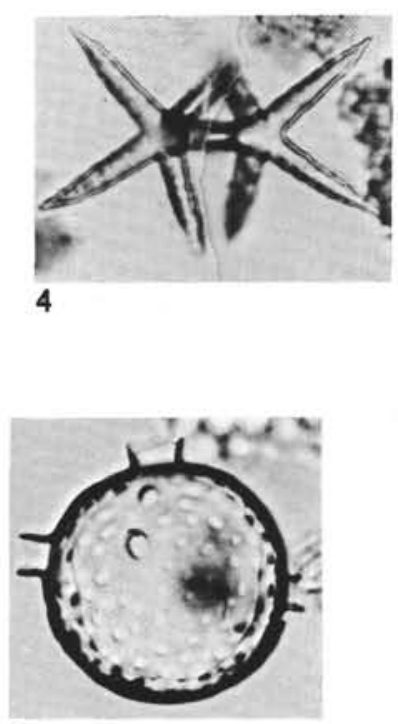

8

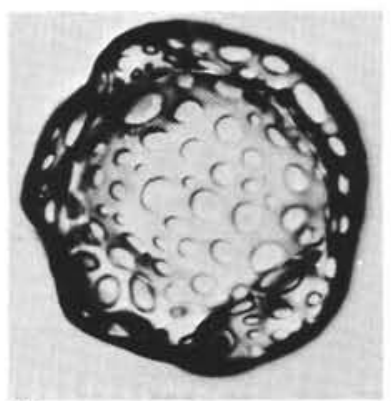

12
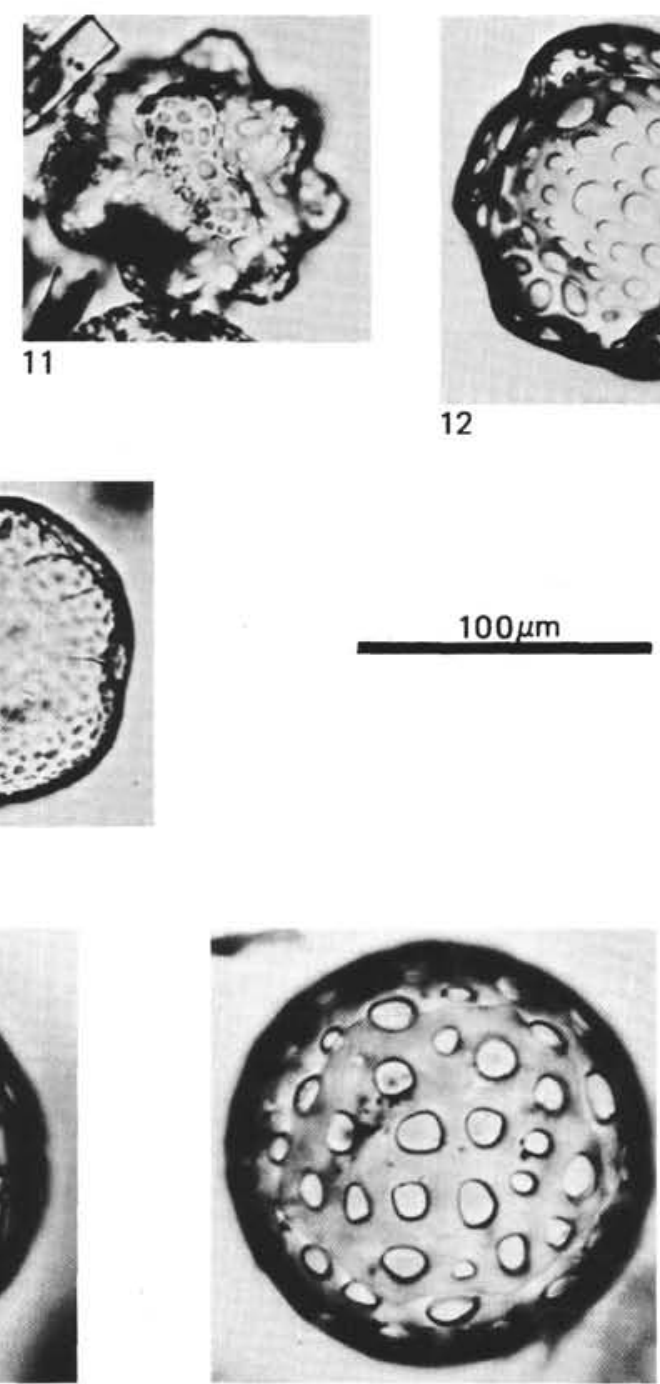

17
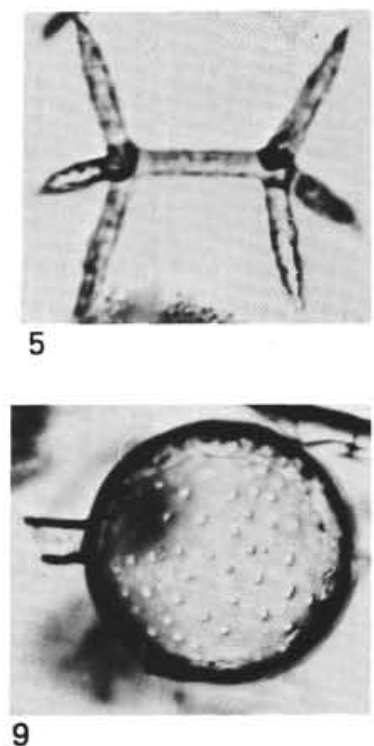

9

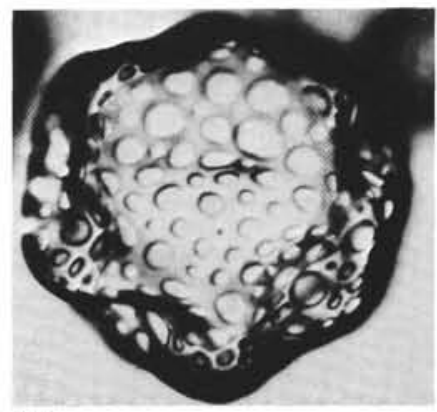

13

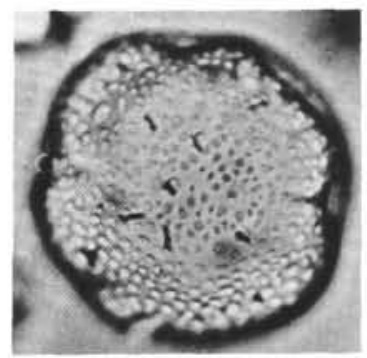

15

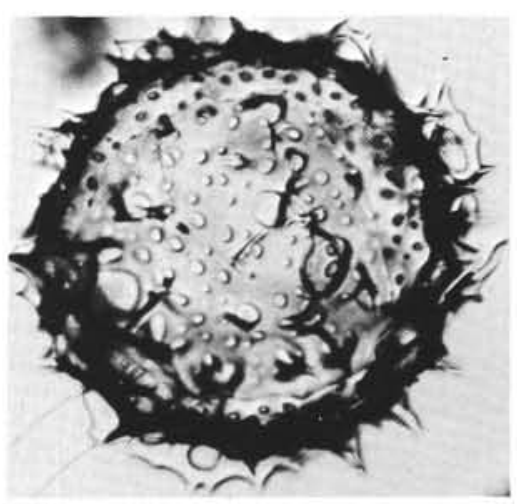

18 
PLATE 2

All figures $\times 300$.

Scale bar equals $100 \mu \mathrm{m}$.

Figures 1, 2 Acrosphaera cyrtodon

1. Sample 428-5-1, 19-21 cm, England finder J21/4.

2. Sample 428-3,CC, England finder Y13/0.

Figures 3-5 Acrosphaera murrayana

3. Sample 428-2-3, 19-21 cm, England finder $\mathrm{U} 15 / 3$.

4. Sample $428-2-4,19-21 \mathrm{~cm}$, England finder $\mathrm{P} 37 / 0$.

5. Sample 427-4-2, 50-52 cm, England finder $\mathrm{U} 42 / 2$.

Figures 6-9 Acrosphaera trepanata

6. Sample 424A-1-1, 19-21 cm, England finder $\mathrm{R} 14 / 0$.

7. Sample 422-1-1, 120-122 cm, England finder D $38 / 0$.

8. Sample 427-3-3, 60-62 cm, England finder O13/0.

9. Sample 427-1-2, 20-22 cm, England finder A11/2. 
PLATE 2
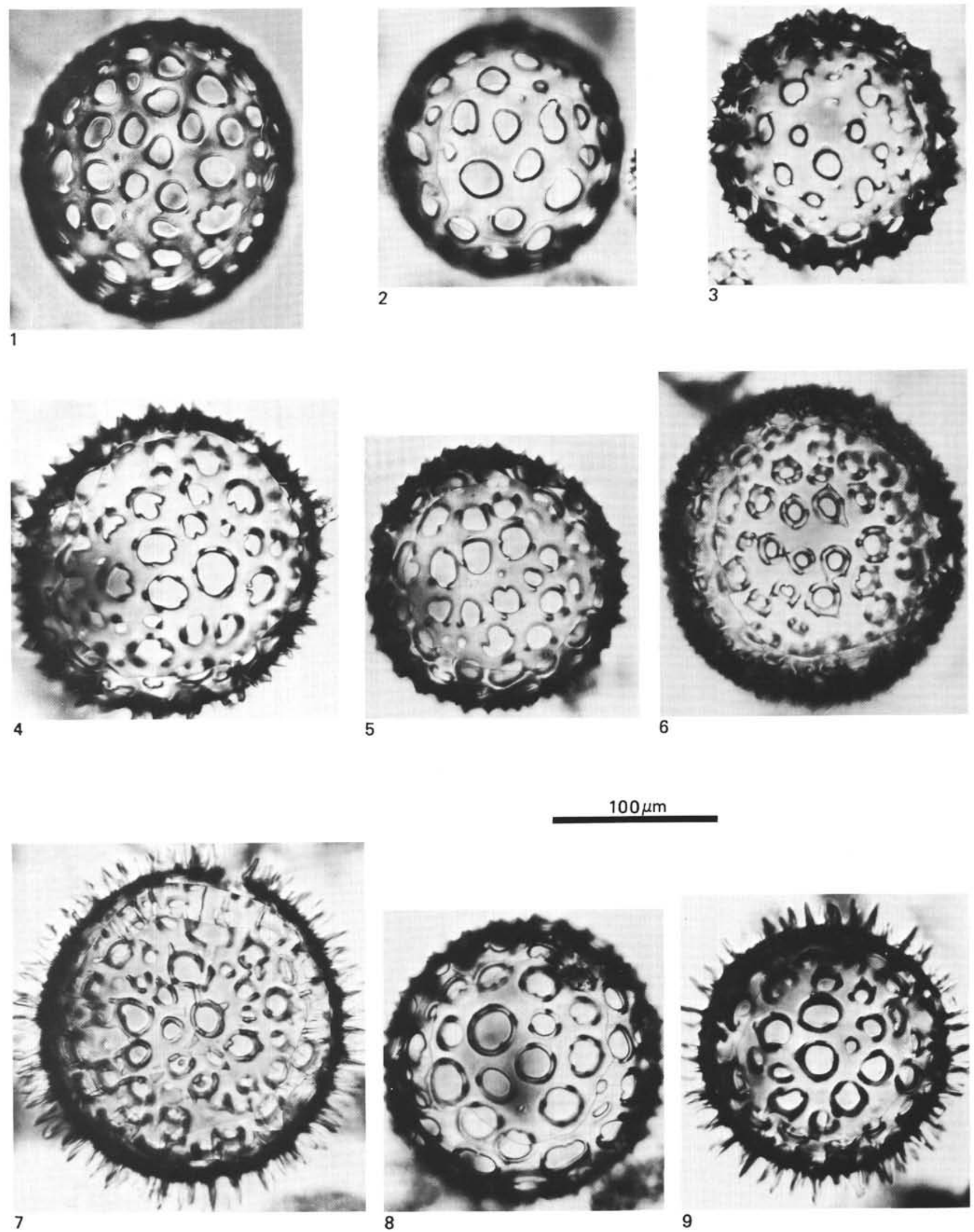


\section{PLATE 3}

All figures $\times 300$.

Figures 1-3 Neosemantis hofferti Goll n. sp.

1. Basal view, Sample 427-8-4, 29-31 cm, England finder V49/3, Paratype USNM 258910.

2. Oblique back view, Sample 420-5, CC, S1. 1, England finder W48/2, Holotype USNM 258909.

3. Oblique right-side view of specimen with right primary lateral apophyse missing, Sample 4283-4, England finder X19/1, Paratype USNM 258911.

Figure $4 \quad$ Pterocanium prismatium

Sample 420-11,CC, S1. 2, England finder R22/3.

Figures 5, $6 \quad$ Pseudocubus warreni Goll, n. sp.

5. Oblique basal view, Sample 425-3-4 (19-21), S1. 1, England finder R57/0, Holotype 258905 .

6. Side view, Sample 425-5-4, 19-21 cm, S1. 1, England finder F52/1.

Figure $7 \quad$ Stylatractus universus Sample 420-12-5, 19-21 cm, S1. 2, England finder $\mathrm{T} 12 / 2$.

Figure $8 \quad$ Lithopera bacca

Sample 428-3,CC, England finder H6/1.

Figure 9 Anthocyrtidium angulare

Sample 420-7-4, 19-21 cm, S1. 1, England finder O46/2.

Figure $10 \quad$ Conarachnium nigriniae

Sample 425-1, CC, S1. 2, England finder F28/3.

Figure 11 Lamprocyrtis neoheteroporus

Sample 420-9-2, 19-21 cm, S1. 1, England finder $\mathrm{P} 10 / 2$.

Figures 12, 13 Lamprocyrtis heteroporus

12. Sample 420-12-5, 19-21 cm, S1. 1, England finder $\mathrm{H} 18 / 3$.

13. Sample 428-5-1, 19-21 cm, England finder $\mathrm{L} 15 / 0$. 
PLATE 3
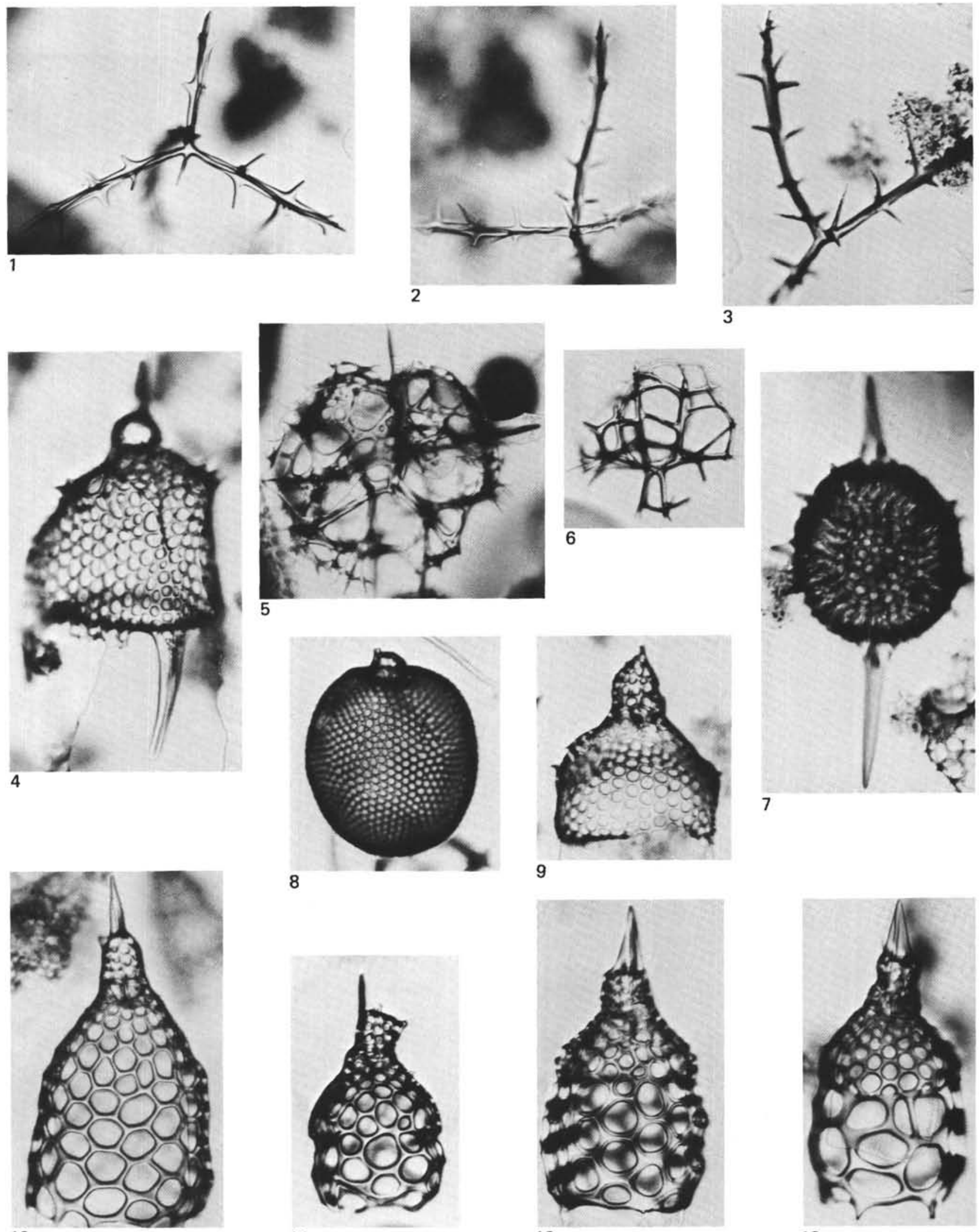

7
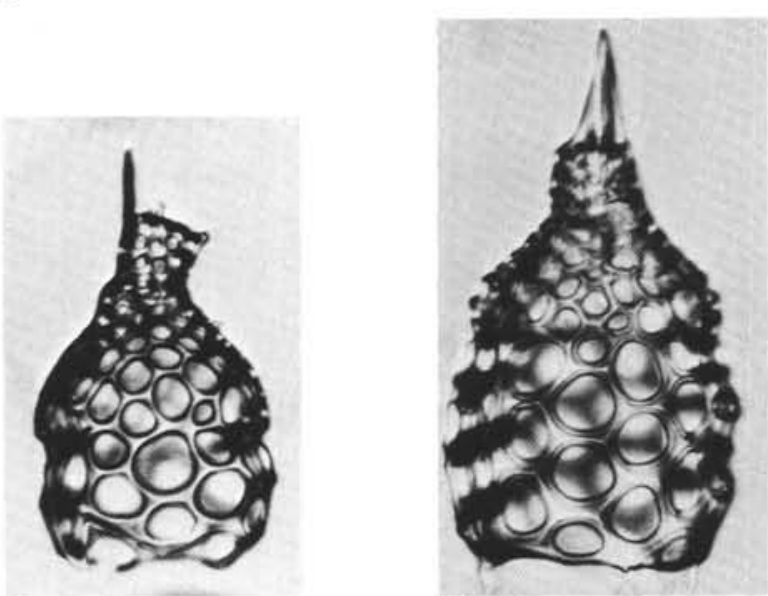

12

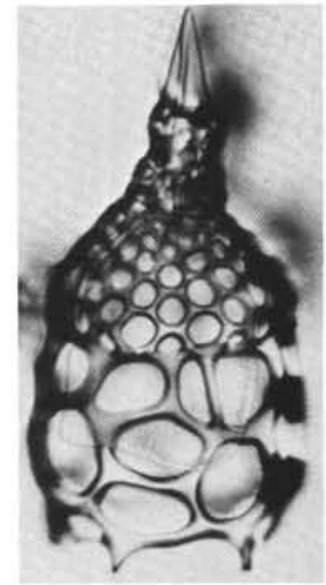


PLATE 4

All figures $\times 300$.

Scale bar equals $100 \mu \mathrm{m}$.

Figure 1 Androspyris fenestrata

1. Sample 420-12-5, 19-21 cm, S1. 1, England finder Q34/3.

Figures 2, 3 Androspyris anthropiscus

2. Front view, Sample 419-4-2, 32-34 cm, S1. 2, England finder Q26/3.

3. Back view, Sample 420-6-1, 19-21 cm, S1. 1, England finder Q13/2.

Figures 4, 5 Androspyris huxleyi

4. Front view, Sample 424C-1-1, 19-21 cm, England finder Q20/1.

5. Front view of specimen with broken frontal spine, Sample 425-1-1, 20-22 cm, S1. 2, England finder E25/4. 
PLATE 4

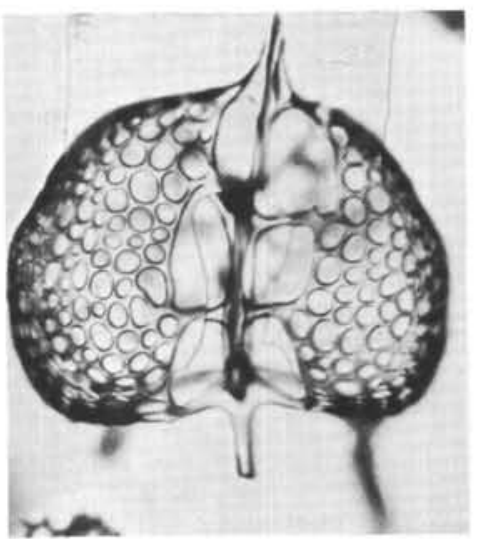

1
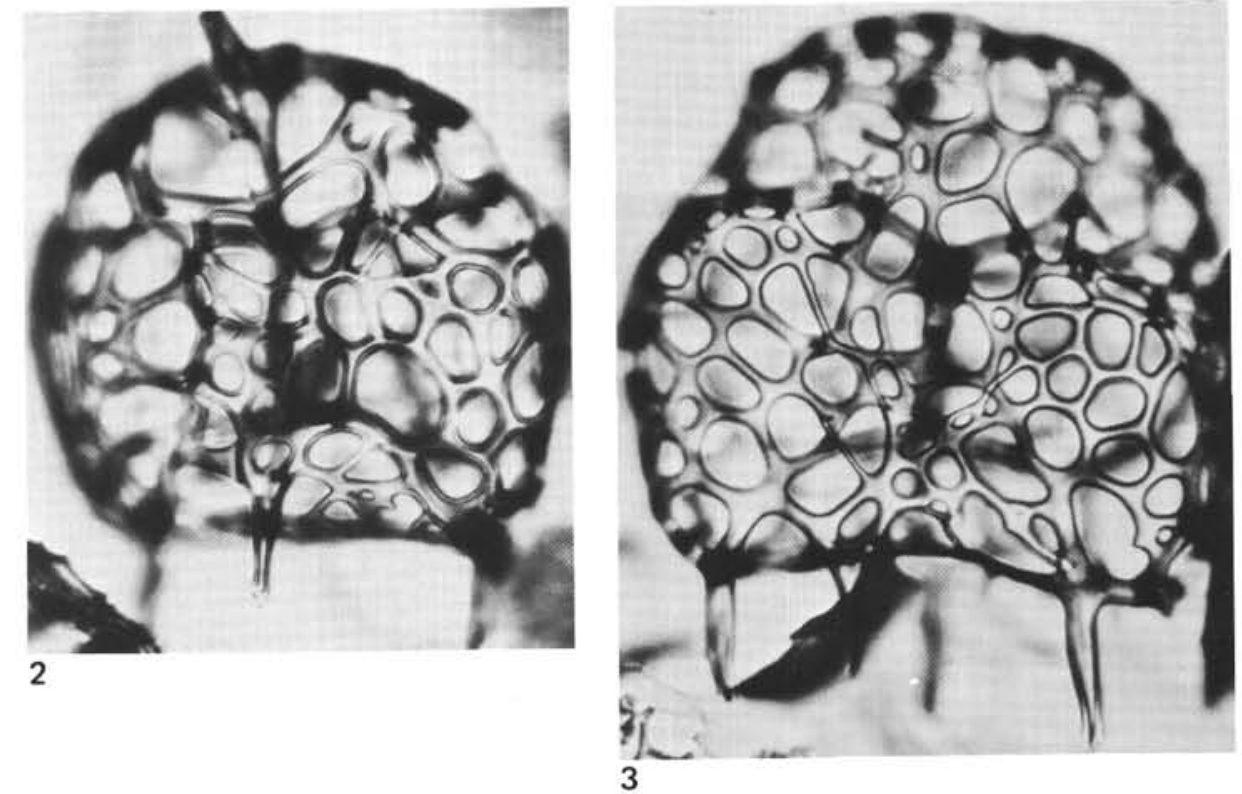
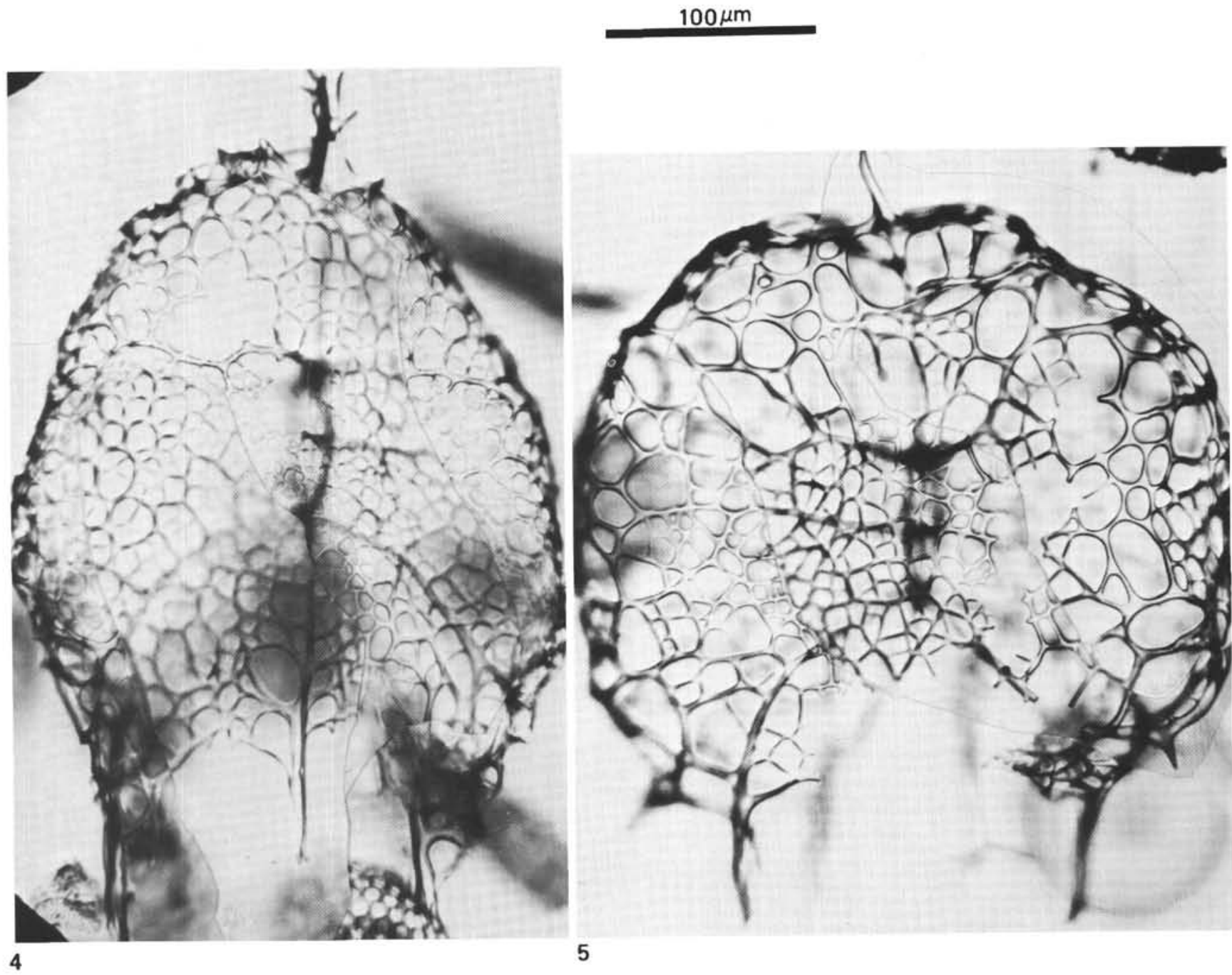
PLATE 5

Both figures $\times 300$.

Figure $1 \quad$ Nephrospyris renilla lana Goll, n. subsp.

Front view, Sample 425-5-4, 19-21 cm, S1. 1, England finder L50/2, Holotype USNM 258908.

Figure 2 Nephrospyris renilla renilla

Front view, Sample 424C-1-1, 19-21 cm, England finder E27/0. 
PLATE 5
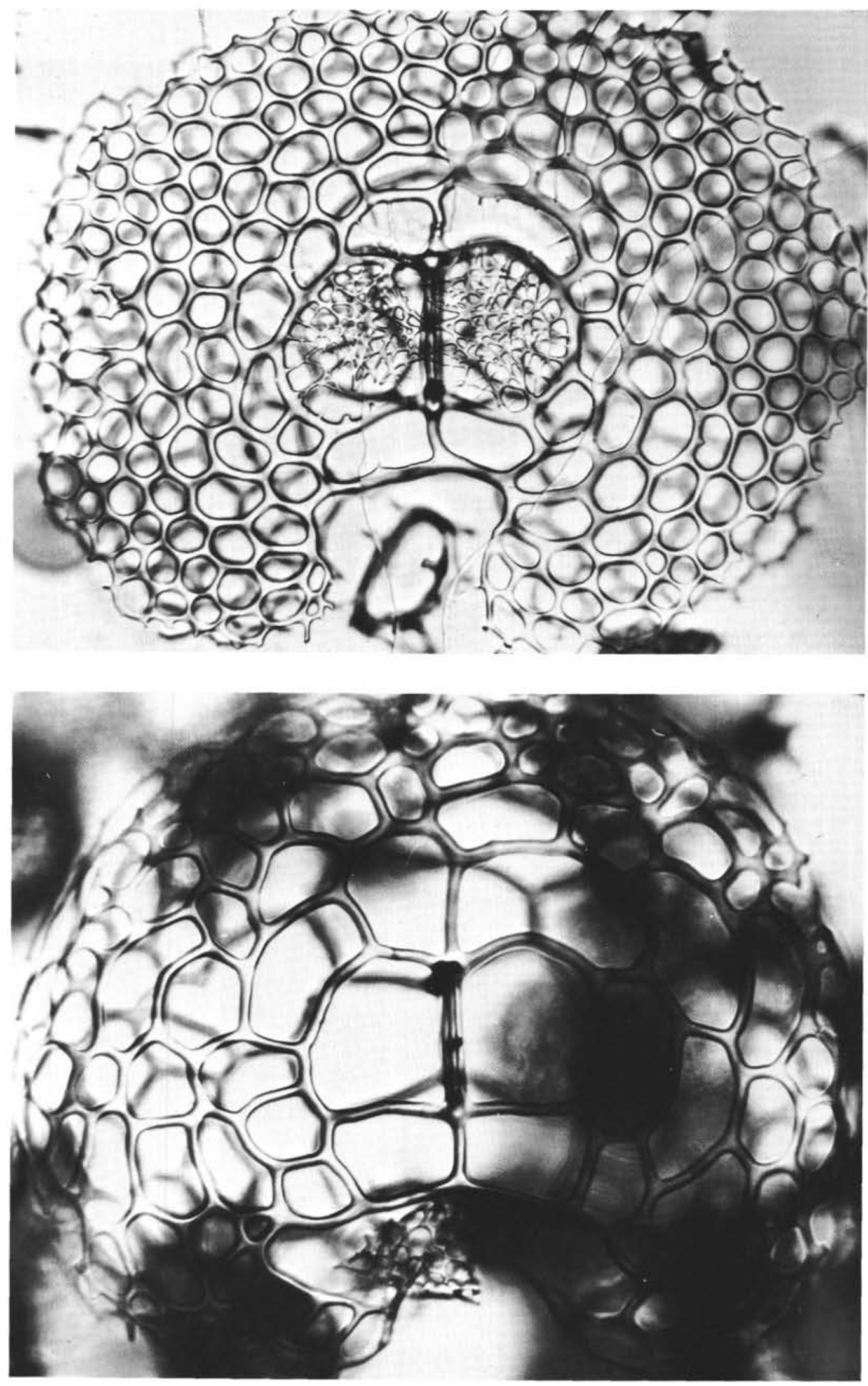
PLATE 6

All figures $\times 300$.

Scale bar equals $100 \mu \mathrm{m}$.

Figures 1, 3, 4 Amphispyris roggentheni Goll, n. sp.

1. Back view, Sample 427-7-1, 19-21 cm, England finder $\mathrm{O} 53 / 1$.

3. Basal view, Sample $425-5-4,19-21 \mathrm{~cm}, \mathrm{~S} 1.2$, England finder Y28/0.

4. Basal view, Sample 428-4-3, 19-21 cm, England finder D53/2.

Figures 2, 5 Amphispyris reticulata

2. Basal view, Sample 427-3-2, 90-92 cm, England finder M14/3.

5. Apical view, Sample $424 C-1-3,19-21 \mathrm{~cm}$, England finder Q11/2. 
PLATE 6
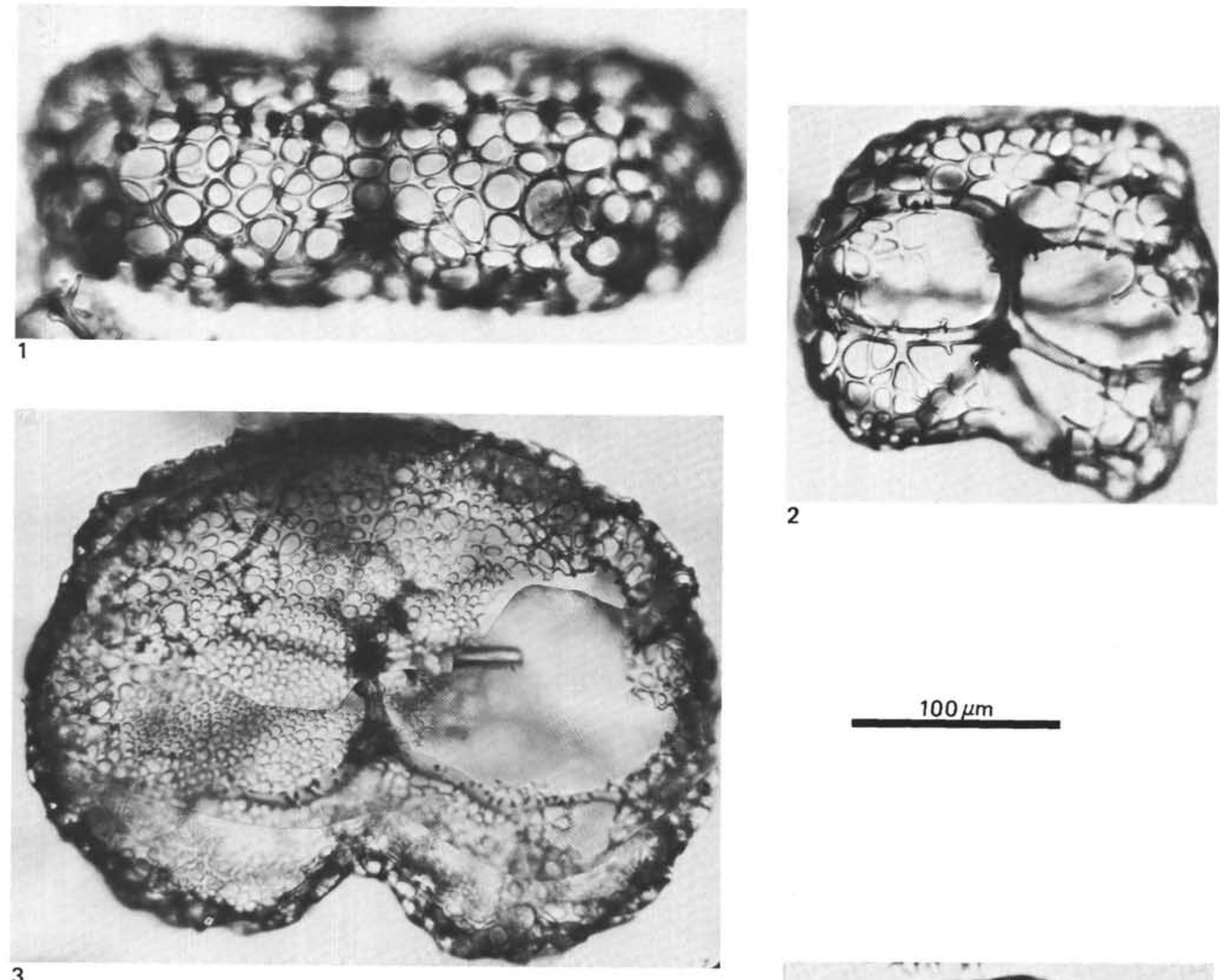

2
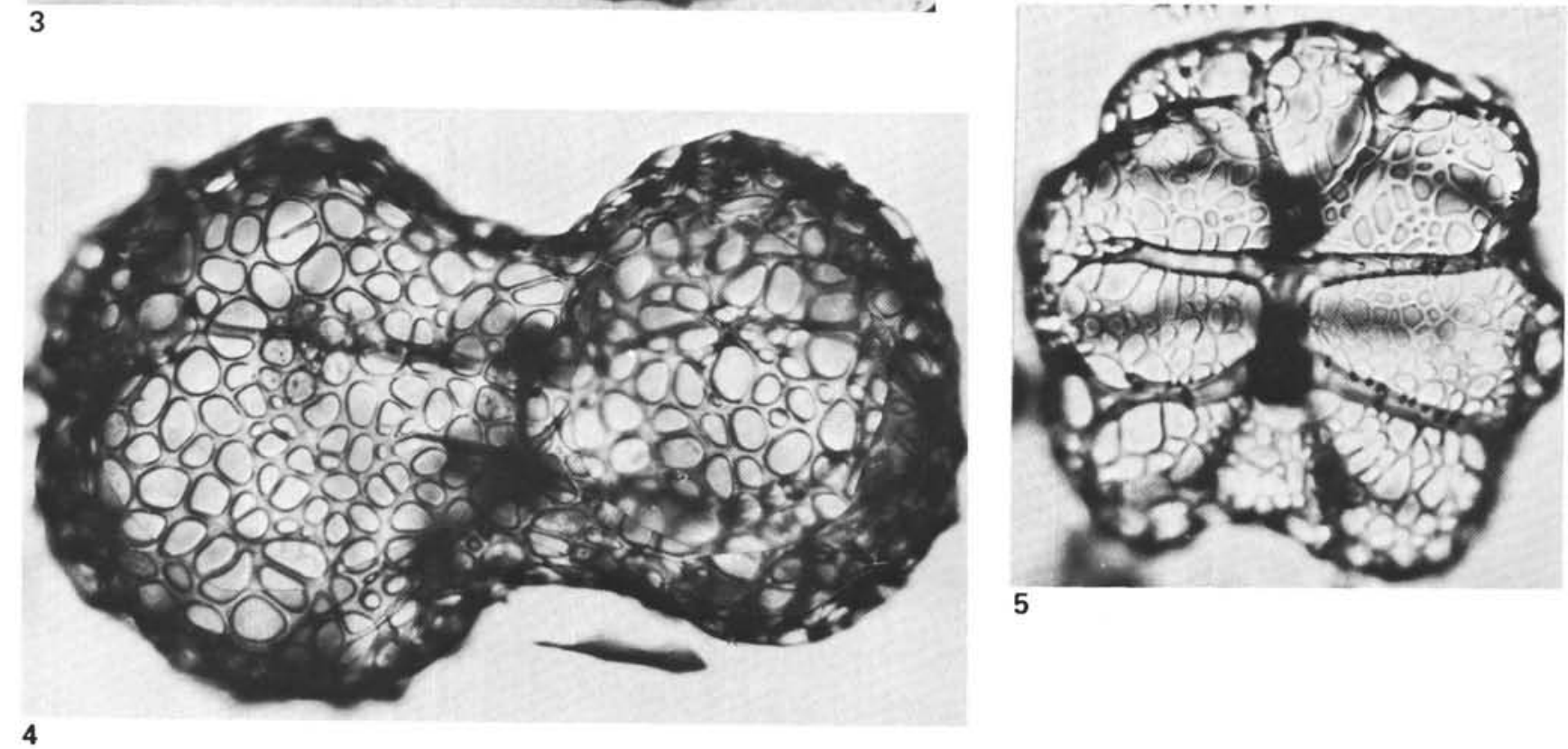

5 
PLATE 7

All figures $\times 300$.

Scale bar equals $100 \mathrm{~mm}$.

Figures 1, 2 Tholospyris devexa finalis

1. Oblique side view, Sample 424-1-1, 0-2 cm, S1. 2, England finder P33/0.

2. Front view, Sample 424C-1-3, 19-21 cm, England finder $\mathrm{T} 33 / 0$.

Figures 3, 5, 7 Tholospyris devexa devexa

3. Front view, Sample 424C-1-5, 19-21 cm, England finder Q48/3.

5. Back view, Sample 427-1-2, 20-22 cm, England finder $\mathrm{C} 20 / 0$.

7. Back view, Sample 423-2-1, 20-22 cm, England finder $\mathrm{P} 33 / 2$.

Figures 4, $6 \quad$ Amphispyris roggentheni Goll, n. sp.

4. Apical view, Sample 422-5-4, 19-21 cm, S1. 2, England finder L12/1, Paratype USNM 258907.

6. Basal view, Sample 428-4-4, 19-21 cm, England finder F24/4, Holotype USNM 258906. 
PLATE 7
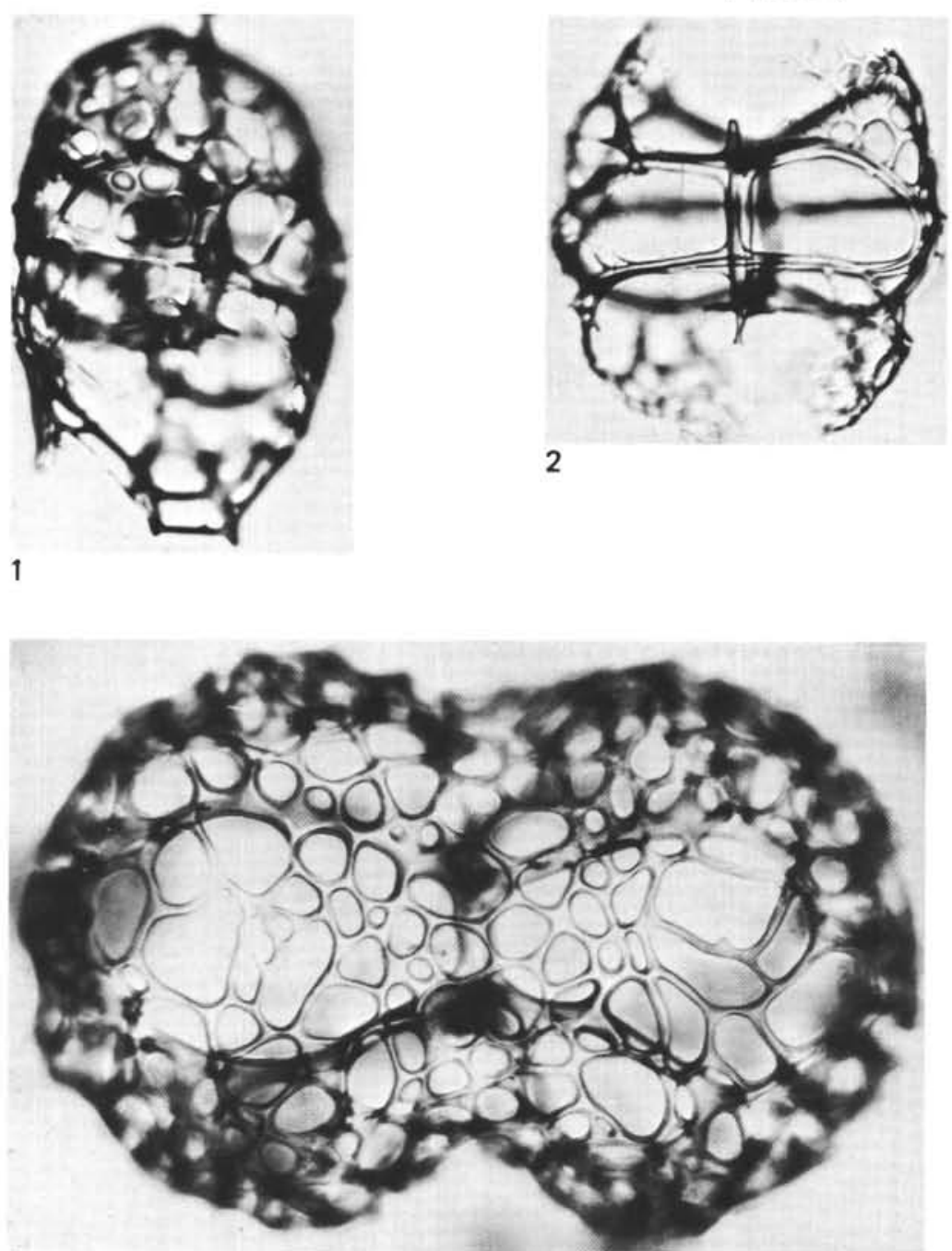

4

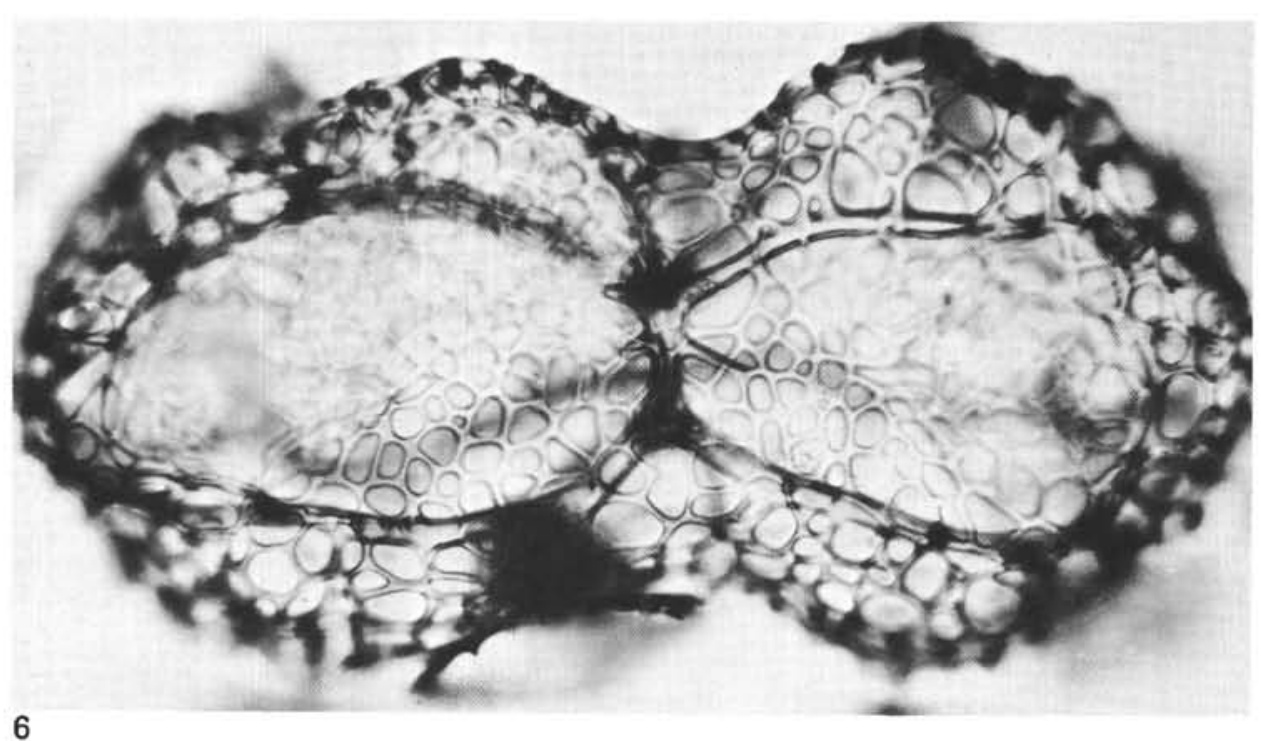

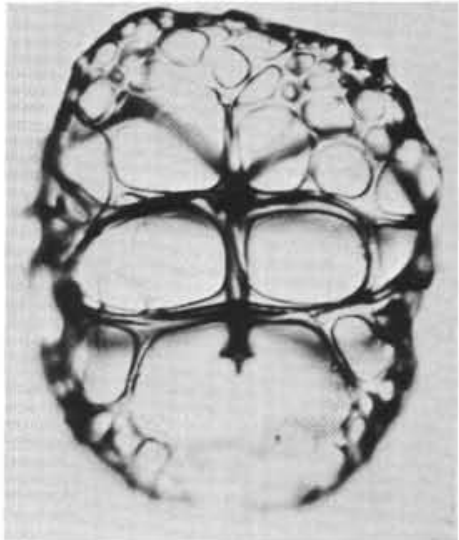

3

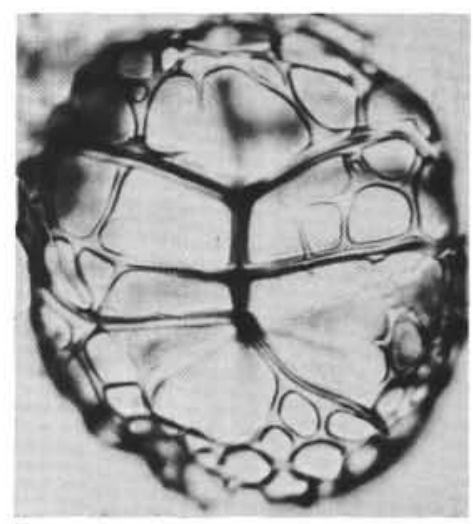

5

$100 \mu \mathrm{m}$

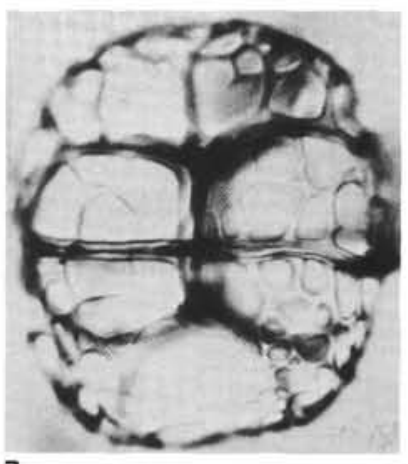

